\title{
Paleoseismology of the North Anatolian Fault at Güzelköy (Ganos segment, Turkey): Size and recurrence time of earthquake ruptures west of the Sea of Marmara
}

\section{Mustapha Meghraoui}

Institut de Physique du Globe de Strasbourg (UMR 7516), F-67084 Strasbourg, France (m.meghraoui@unistra.fr)

\section{Ersen Aksoy}

Institut de Physique du Globe de Strasbourg (UMR 7516), F-67084 Strasbourg, France

Eurasia Institute of Earth Sciences, Istanbul Technical University, 34469 Istanbul,

Turkey

Now at Instituto Dom Luiz, Universidade de Lisboa, P-1750-129 Lisbon, Portugal

\section{H. Serdar Akyüz}

Department of Geology, Faculty of Mines, Istanbul Technical University, Maslak, 34469 Istanbul, Turkey

\section{Matthieu Ferry}

Institut de Physique du Globe de Strasbourg (UMR 7516), F-67084 Strasbourg, France

Now at Geosciences Montpellier, F-34095 Montpellier, France

\section{Aynur Dikbaş}

Eurasia Institute of Earth Sciences, Istanbul Technical University, 34469 Istanbul,

Turkey

Department of Geology, Faculty of Mines, Istanbul Technical University, Maslak, 34469

Istanbul, Turkey

\section{Erhan Altunel}

Department of Geology, Eskişehir Osmangazi University, 26480 Eskişehir, Turkey

[1] The Ganos fault is the westernmost segment of the North Anatolian Fault that experienced the Mw $=7.4$ earthquake of 9 August 1912. The earthquake revealed 45-km-long of surface ruptures inland, trending $\mathrm{N} 70^{\circ} \mathrm{E}$, and $5.5 \mathrm{~m}$ of maximum right lateral offset near Güzelköy. The long-term deformation of the fault is clearly expressed by several pull-apart basins and sag ponds, pressure and shutter ridges and offset streams. In parallel with detailed geomorphologic investigations, we measured co-seismic and cumulative displacements along the fault, and selected the Güzelköy site for paleoseismology. A microtopographic survey at the site yields $10.5 \pm 0.5 \mathrm{~m}$ and $35.4 \pm 1.5 \mathrm{~m}$ cumulative lateral offsets of stream channels and geomorphologic features. Seven paleoseismic parallel and cross-fault trenches document successive faulting events and provide the timing of past earthquakes on the Ganos fault segment. Radiocarbon dating of successive colluvial wedges in trench T1, and the fresh scarplet above (probably 1912 surface rupture) 
indicate the occurrence of three faulting events since the 14th century. Parallel trenches $(3,5,6$ and 7$)$ expose paleo-channels and show a cumulative right-lateral offset of $16.5 \pm 1.5 \mathrm{~m}$ next to the fault, and $21.3 \pm 1.5 \mathrm{~m}$ total channel deflection. Radiocarbon dating of past channel units and fault scarp-related colluvial deposits imply an average $17+/-5 \mathrm{~mm} /$ year slip rate and $323 \pm 142$ years recurrence interval of large earthquakes during the last 1000 years on the Ganos fault. The succession of past faulting events and inferred slip rate west of the Marmara Sea provide more constraint on the long-term faulting behavior in the seismic gap of the North Anatolian Fault and may contribute to a better seismic hazard assessment in the Istanbul region.

Components: 14,800 words, 14 figures, 5 tables.

Keywords: 1912 Mürefte earthquake; Ganos fault segment; Marmara; North Anatolian Fault; paleoseismology.

Index Terms: 7221 Seismology: Paleoseismology (8036); 7230 Seismology: Seismicity and tectonics (1207, 1217, 1240, 1242); 8111 Tectonophysics: Continental tectonics: strike-slip and transform.

Received 14 November 2011; Revised 29 February 2012; Accepted 1 March 2012; Published 12 April 2012.

Meghraoui, M., M. E. Aksoy, H. S. Akyüz, M. Ferry, A. Dikbaş, and E. Altunel (2012), Paleoseismology of the North Anatolian Fault at Güzelköy (Ganos segment, Turkey): Size and recurrence time of earthquake ruptures west of the Sea of Marmara, Geochem. Geophys. Geosyst., 13, Q04005, doi:10.1029/2011GC003960.

\section{Introduction}

[2] The record of past earthquakes in superficial geological units is a key element in paleoseismological investigations. As generally observed in trenches, the repeated surface faulting with significant co-seismic slip characterizes the size and recurrence time of past seismic events. The 9 August 1912 Mürefte earthquake $\left(\mathrm{M}_{\mathrm{s}}=7.3\right.$ [Ambraseys, 2002]) occurred along the western section of the North Anatolian Fault (NAF) and displayed surface faulting along the 45-km-long inland section of the Ganos segment (Figures 1 and 2). The earthquake caused human loss and severe damage in a wide area and affected cities such as Şarköy, Mürefte and Gaziköy in the epicentral area [Ambraseys and Finkel, 1987; Sadi, 1912; Mihailovic, 1927]. Coseismic surface rupture and slip, showing up to $5.5 \mathrm{~m}$ right-lateral offsets, were described in contemporaneous reports and more recent studies (Figure 2) [Mihailovic, 1927; Altunel et al., 2004; Aksoy et al., 2010]. According to photographs taken soon after the main shock [Mihailovic, 1927], the surface breaks exhibited linear fault scarps, mole tracks and en-echelon ruptures similar to those observed during the 17 August 1999 İzmit earthquake (Mw 7.4 [Barka et al., 2002]). The geomorphology along the fault strike shows that in several locations, the 1912 co-seismic offset coincides with cumulative offset observed on streams, ridges and old path deflections. This coincidence indicates a localized coseismic surface deformation on the same fault branch. Hence, the consistent repetition of co-seismic movements on the same fault rupture offers the possibility to identify the trace of paleoearthquakes. The paleoseismology of the Ganos fault may therefore provide some constraints on the timing of past earthquakes and slip rate on the NAF immediately west of the Sea of Marmara.

[3] Paleoseismology includes various field techniques that involve crosscutting and parallel trenching and isotopic dating of sedimentary units aided with topographic surveys and sometimes shallow geophysics [McCalpin, 2009]. The size and characteristics of past earthquake ruptures are accessible through detailed field studies along the North Anatolian Fault [Rockwell et al., 2001; Klinger et al., 2003; Ferry et al., 2004; Hartleb et al., 2006; Palyvos et al., 2007; Pantosti et al., 2008; Rockwell et al., 2009; Fraser et al., 2010; Kondo et al., 2010; Zabcr et al., 2011; Dikbaş and Akyüz, 2011]. Previous paleoseismic investigations along the Ganos fault segment focused near the Saros Bay at the westernmost section of the 1912 rupture, and determined four surface ruptures during the past 1100 years [Rockwell et al., 2001]. More recent trenching studies at the Saros Bay constrained four surface faulting after AD 900 and displayed a $9 \pm 1 \mathrm{~m}$ channel offset related to the last two events [Rockwell et al., 2009]. Paleoearthquakes of the Saros Bay region are likely to correspond to the 1063 and 1343 or 1354, 1659 or 1766 and 1912 historical seismic events [Rockwell et al., 2009; Aksoy, 2009]. 


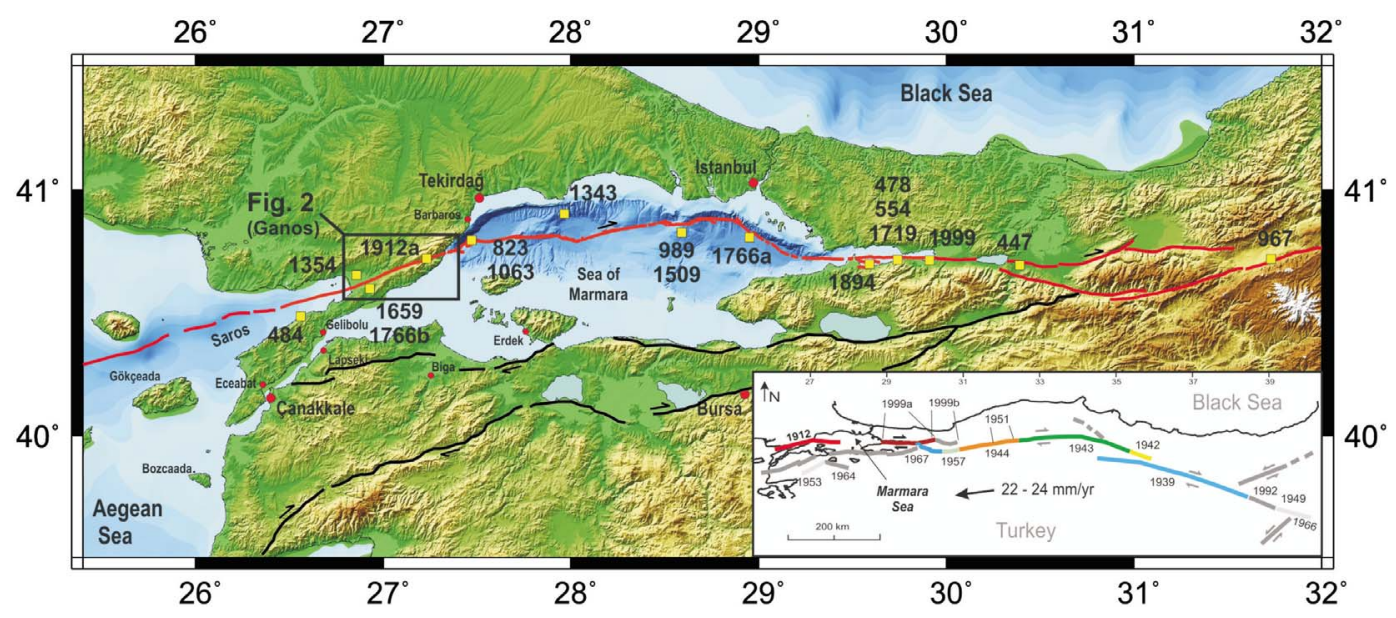

Figure 1. The North Anatolian Fault (NAF, red and black lines) in the Marmara Sea and neighboring regions. The Ganos fault segment is the site of the 9 August 1912 earthquake (Mw 7.4 [Aksoy et al., 2010]) and represents the westernmost fault segment of the NAF (red line for northern branch, and black line for southern branch). Yellow boxes are historical earthquakes [Ambraseys, 2002], and the simplified fault zone in the Marmara Sea bottom is according to Armijo et al. [2005]. The inset shows the 1939-1999 earthquake sequence and geodetic rate along the NAF and the location of the 1912 out of sequence earthquake segment [Barka, 1996; Hubert-Ferrari et al., 2000; Reilinger et al., 2006].

[4] The study of rupture dimension using the 1912 co-seismic slip distribution, fault geometry and the analysis of seismic records suggests a total length of $140 \pm 20 \mathrm{~km}$ for the $1912 \mathrm{Mw} 7.4$ rupture which determines the western limit of the Sea of
Marmara seismic gap [Aksoy, 2009; Aksoy et al., 2010]. As the total 1912 co-seismic rupture length supersedes the 45-km-long inland Ganos fault, a significant fault section is located offshore. Offshore investigations of the fault rupture were

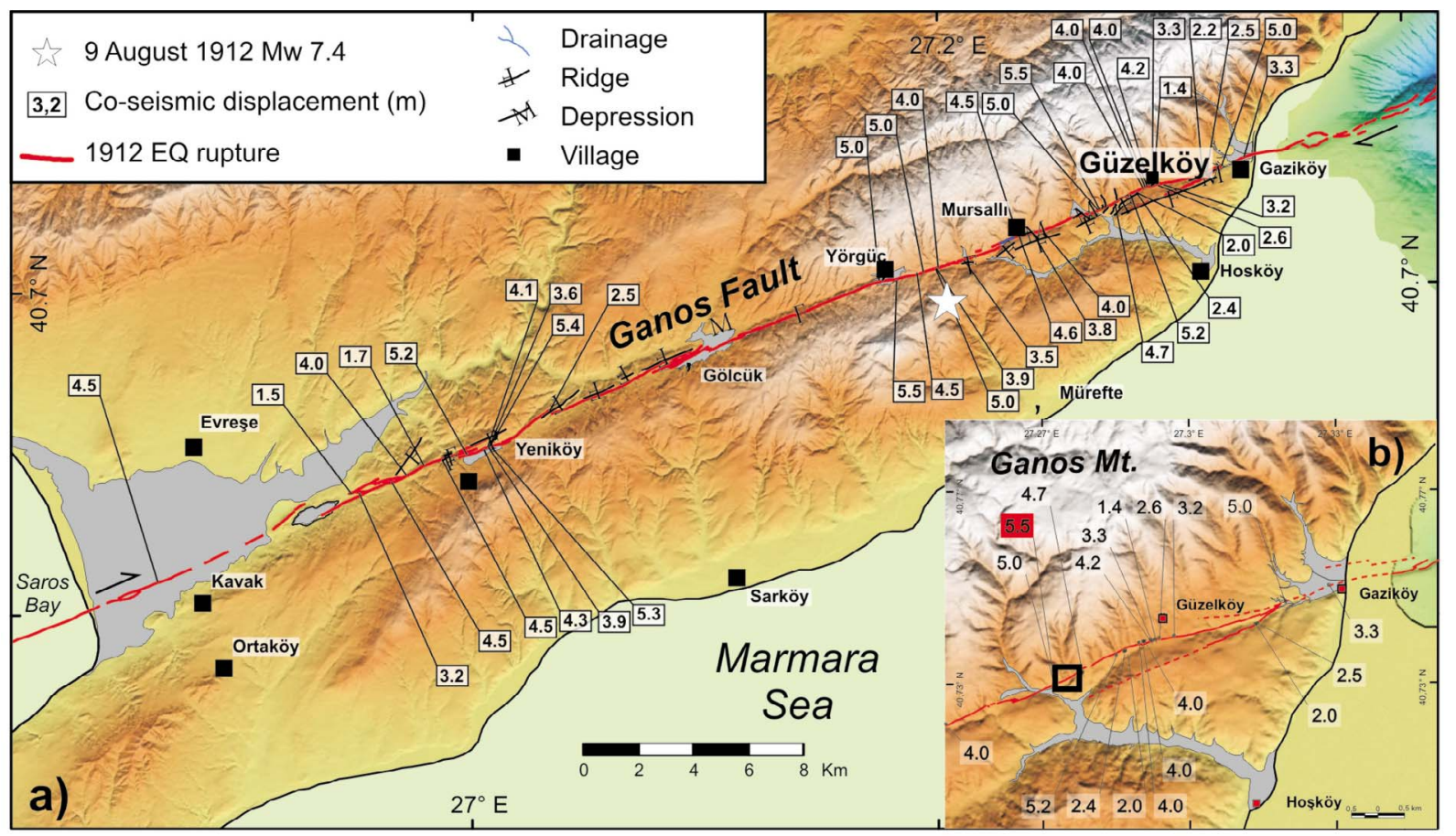

Figure 2. (a) The Ganos fault inland (red line) and 1912 right-lateral coseismic slip in boxes [Aksoy et al., 2010]. The star represents the 1912 epicenter location according to Ambraseys [2002]. The Güzelköy paleoseismic site is in the NE section of the fault. (b) The paleoseismic site is in box on the 1912 fault (red line) with slip distribution (numbers) indicating a zone maximum right-lateral slip (maximum $5.5 \mathrm{~m}$ in red [Aksoy, 2009]). 
Table 1. Major Historical Seismic Events $(M>6.8)$ of the Northern Branch of the NAF (Figure 1) and Affected the Western Sea of Marmara Region, With Maximum $100 \mathrm{~km}$ Distance to Mürefte (Figure 2)

\begin{tabular}{lccccc}
\hline \multicolumn{1}{c}{ Date $(\mathrm{yr} / \mathrm{m} / \mathrm{d})$} & Lat. & Lon. & $\mathrm{M}_{\mathrm{s}}{ }^{\mathrm{a}}$ & $\mathrm{I}_{\mathrm{o}}$ & Localities With Heavy Damage \\
\hline $477.08 .25 / 484.09 .00$ & 40.8 & 29.5 & 7.2 & $\mathrm{IX}^{\mathrm{a}, \mathrm{b}}$ & Çanakkale, Gelibolu, Saros \\
$823(824 ?) .10$ & 40.9 & 27.4 & - & $\mathrm{IX}^{\mathrm{a}, \mathrm{b}}$ & Panion (Barbaros), Marmara Ereğli \\
1063.09 .23 & 41.0 & 29.0 & 7.4 & $\mathrm{IX}^{\mathrm{c}}$ & Saros, Mürefte, Tekirdağ, İstanbul \\
1343.10 .18 & 41.0 & 29.0 & 7 & $\mathrm{VIII}^{\mathrm{c}}$ & İstanbul \\
1344.11 .06 & 40.7 & 27.4 & - & $\mathrm{IX}^{\mathrm{c}}$ & Tekirdağ, İstanbul, \\
1354.03 .01 & 40.6 & 26.9 & 7.4 & $\mathrm{X}^{\mathrm{c}}$ & Ţanakkale, Gelibolu, Saros, Tekirdağ \\
1659.02 .17 & 40.5 & 26.4 & 7.2 & - & Tekirdağ \\
1766.05 .22 & 41.0 & 29.0 & 7.4 & - & Istanbul, Bosphorus, Gulf of Mundaya, Bursa, Izmit, Tekirdăg \\
1766.08 .05 & 40.6 & 27.0 & 7.4 & - & Bozcaada, Çanakkale, Gelibolu, Saros, Tekirdağ \\
1912.08 .09 & 40.7 & 27.2 & 7.3 & $\mathrm{X}^{\mathrm{d}}$ & Gelibolu, Saros, Tekirdağ \\
1912.09 .13 & 40.7 & 27.0 & 6.9 & $\mathrm{VII}^{\mathrm{e}}$ & Gelibolu, Saros, Mürefte \\
\hline
\end{tabular}

${ }^{a}$ Ambraseys [2002, 2009].

${ }^{\mathrm{b}}$ Guidoboni et al. [1994].

${ }^{\mathrm{c}}$ Guidoboni and Comastri [2005].

${ }^{\mathrm{d}}$ Ambraseys and Finkel [1987].

${ }^{\mathrm{e}}$ Hecker [1920].

conducted in both the Sea of Marmara [Le Pichon et al., 2003; Armijo et al., 2005; Uçarkuş et al., 2011] and the Aegean Sea [McNeill et al., 2004; Ustaömer et al., 2008; Gasperini et al., 2011] where 100-kmlong fault scarps with cumulative slip were clearly observed in the seafloor. Correlated to the total inland and offshore fault length, the 1912 slip distribution onland may serve as a reference for previous earthquake ruptures if characteristic fault behavior [Schwartz and Coppersmith, 1984] is adopted for the Ganos fault segment.

[5] In this paper, we present paleoseismic investigations on the 1912 rupture along the Ganos fault segment. The Güzelköy trench site located close to the Marmara shoreline has been selected because it displays sequentially offset streams and ridges, and faulted young sedimentary deposits that may reveal evidence of several seismic events. Three crosscutting trenches and four parallel trenches to the fault have been excavated in order to depict past surface-rupturing events and right-lateral slip rate during the late Holocene. The results that combine the dated cumulative dextral slip with faulting events identified in trenches are discussed in the frame of other paleoseismic studies performed along the Ganos fault segment and NAF. Finally, we also discuss the contribution of paleoseismological results and their implication to the seismic hazard assessment of the Sea of Marmara and greater Istanbul region.

\section{Seismotectonic Setting}

[6] The NAF is an E-W trending and $\sim 1500 \mathrm{~km}-$ long, broad arc-shaped main continental fault (Figure 1) that forms the boundary between Eurasia and Anatolia plates [Şengör et al., 1985; Şaroğlu et al., 1992]. The right lateral strike-slip fault system is made of several segments limited by major geometrical discontinuities showing releasing and restraining bends along strike [Barka and Kadinsky-Cade, 1988]. The NAF is generally narrow in the east, forming a single rupture strand, but it widens in the west forming two main fault branches (Figure 1). The northern branch that crosses the Sea of Marmara [Le Pichon et al., 2003] was the site of numerous destructive earthquakes in the past [Ambraseys, 2002], the most recent large $\left(\mathrm{M}_{\mathrm{s}} \geq 7.3\right)$ events being the 9 August 1912 and 17 August 1999 earthquakes that occurred west and east of the Sea of Marmara, respectively (Figure 1 and Table 1).

[7] The NAF across the Sea of Marmara shows evidence of long-term kinematics and strain release with $70 \mathrm{~km}$ total right-lateral displacement on the Ganos fault, which implies $\sim 14 \mathrm{~mm} / \mathrm{yr}$ right lateral slip-rate for the last $5 \mathrm{Ma}$ [Armijo et al., 1999] or $\sim 20 \mathrm{~mm} / \mathrm{yr}$ for the last $3.5 \mathrm{Ma}$ [Yalttrak et al., 2000]. From paleoseismic investigations in the Saros Bay and assuming an average $4.5 \mathrm{~m}$ characteristic slip for each major historical earthquake, Rockwell et al. [2009] estimate $\sim 16 \mathrm{~mm} / \mathrm{yr}$ slip rate for the past $1.2 \mathrm{ka}$ along the Ganos fault. GPS measurements indicate that the northern branch of the NAF in the Sea of Marmara region accommodates a significant part of the present-day active deformation with $22-26 \mathrm{~mm} / \mathrm{yr}$ geodetic strain rate [McClusky et al., 2000; Reilinger et al., 2006]. However, recent estimates of geological slip-rates carried out on both sides of the Marmara pull-apart (i.e., Gulf of İzmit and Saros Bay) suggest that geodetic slip rates may overestimate the fault 
cumulative slip during several earthquake cycles [Polonia et al., 2004; Gasperini et al., 2011].

[8] The North Anatolian Fault experienced a westward propagating earthquakes sequence in the 20th century, the most recent large events taking place in 17 August (Mw 7.4) and 12 November (Mw 7.2) 1999 east of the Sea of Marmara (Figure 1) [Barka et al., 2002; Akyüz et al., 2002]. The western Marmara region also suffered intensively in the past from several earthquakes reported with certain details by historical accounts. At least 10 seismic events are known to have affected the Ganos - Gelibolu region over the last 1500 years. The most significant seismic events possibly related to the Ganos fault segment according to their damage distribution (as reported by Ambraseys [2002, 2009], Guidoboni et al. [1994] and Guidoboni and Comastri [2005]) are summarized in Table 1 and here below.

\subsection{AD 484 Gelibolu - Bozcaada $\left(M_{s} 7.2\right)$}

[9] The AD 484 tremor caused widespread damage; mainly in the Dardanelles region, Gelibolu (Callipolis), Lapseki (Lampacus), Çanakkale (Abydus) and Bozcaada island (Tenedos) [Ambraseys, 2009]. The damage to the east extends to Ortaköy at the Saros bay (near Kavak Köy) where 50 towers of the long defensive walls of the Gallipoli peninsula (Chersonesus Thracica) collapsed [Ambraseys, 2009]. Further east, minor damage is reported in Istanbul (Constantinople). The damage distribution also suggests an epicenter around Saros offshore, however the lack of detailed information infers that faulting may have occurred along the onland section of the Ganos fault.

\subsection{October/824 Barbaros - Tekirdağ (Panium)}

[10] Information on this shock is limited, but historical accounts note an earthquake that caused the city walls of Tekirdağ (Panium) to collapse so that Emperor Michael II (AD 820-829) could easily march in and conquer the city [Guidoboni et al., 1994; Ambraseys, 2009]. Damage in Istanbul region is not mentioned. Considering that the earthquake was large enough to destroy an important part of the city walls at Tekirdağ, it may have reached $\mathrm{I}_{\mathrm{o}}$ IX and took place on the Ganos fault or further west in the Saros Bay.

\subsection{3 (23 September) Marmara $\left(M_{s} 7.4\right)$}

[11] In the work of Ambraseys [2009], this event is given as a large shock causing destruction in a region extending from Tekirdağ to Erdek, and Dardanelles Canakkale. Particular damage is described for the western villages of Marmara; like Mürefte (Myriophyto), Barbaros (Panion) and Tekirdağ (Redestos), where aqueducts, churches and other public buildings were thrown down. Only slight damage has been reported in Istanbul (Constantinople). Guidoboni and Comastri [2005] note that several large shocks occurred in the following 2 years, with decrease of frequency and magnitude. The damage concentration in the Western Marmara implies that the earthquake may have occurred on the Ganos fault.

\subsection{3 (18 October) / 1344 (6 November) Sea of Marmara $\left(M_{s} 7.0\right)$}

[12] After a week of foreshocks, two large earthquakes occurred on 18 October 1343 with some hours interval [Ambraseys, 2002; Guidoboni and Comastri, 2005]. The first shock affected the Ganos region. Walls and 2/3 of houses in Hoşköy (Chora) collapsed, killing 300 people. Intensive damage is reported in Mürefte (Myriophyto) and a castle on the Marmara Island collapsed. Bolayır (Lysimachia), Gelibolu (Gallipoli) and other regions in Thrace were also affected by the first tremor. The second (main?) shock damaged a larger region including Istanbul, where the already weakened city walls and some houses suffered heavy damage [Ambraseys, 2009]. This event triggered tsunami waves reported up to Beylerbeyi (Stavros) at Istanbul reaching $\sim 1.5 \mathrm{~m}$ height and extending $1.8 \mathrm{~km}$ into land, drowning people and herds [Guidoboni and Comastri, 2005; Ambraseys, 2009]. Aftershocks lasted for nearly one year, and indicate a large magnitude for the main shock(s). Another large shock also related to the 1343 earthquake sequence [Ambraseys, 2009] is also reported to occur on 6 Nov. 1344 with significant destruction particularly in the Ganos region (Hoşköy) [Guidoboni and Comastri, 2005]. Based on this information, the earthquake rupture(s) can be located offshore in the western part of the Sea of Marmara and may have likely extended inland toward the Ganos fault segment, or further west in the Saros Bay.

\subsection{4 (1 March) Gelibolu ( $\left.M_{s} 7.4\right)$}

[13] The shock caused destruction in an area extending from Tekirdağ (Redestos) to Eceabat (Madytos), Gelibolu (Gallipoli) and Bozcaada (Tenedos). This large seismic event is well documented because it enabled the Ottoman army to take-over the Gelibolu castle, expand toward Europe and conquer Constantinople (now Istanbul) in 1453 [Ambraseys, 2009]. The shock destroyed a large number of 
houses and city walls in the coastal villages of northwestern Marmara and made many victims [Guidoboni and Comastri, 2005]. The destructions are concentrated in the western Marmara region and suggest faulting either along the Ganos fault or further west in the Saros Bay.

\subsection{9 (17 February) Saros $\left(M_{s} 7.2\right)$}

[14] The 1659 earthquake was felt in a very large area extending from Marmara to Manisa and İzmir, but it ruined only buildings in the Çanakkale and Tekirdağ regions. In Istanbul chimneys and the Süleymaniye Mosque suffered some damage. Although the historical accounts on the event are limited, Ambraseys [2009] assigns a large earthquake magnitude and an epicenter location nearby the Saros Bay.

\subsection{6b (5 August) Sea of Marmara $\left(\mathrm{M}_{\mathrm{s}} \mathbf{7 . 4 )}\right.$}

[15] Following the major earthquake of 22 May 1766 that struck Istanbul and its vicinity, this second large shock occurred on 5 August affecting the western regions of Marmara. Tekirdağ, Ganos (Gaziköy) and Gelibolu suffered a lot of destruction and damage extending to Bursa, Istanbul, Biga and Thrace regions. Nearly all villages along the onland section of the Ganos fault suffered intense damage (e.g., Gaziköy, Gölcük, Güzelköy, Yeniköy, Şarköy etc.). $90 \%$ of houses were destroyed in the Ganos region and half of the villages in Gelibolu. Castles in Saros, Seddülbahir, Kilitbahir and Bozcaada experienced heavy damage. Surface cracks and liquefaction nearby Gelibolu were also observed. The damage in Istanbul was not severe.

[16] Taking into account the historical seismicity during the last millennium [Ambraseys, 2002] and the $283 \pm 113$ years average recurrence time obtained from paleoseismic studies [Rockwell et al., 2009], it appears that the Sea of Marmara fault zone is the site of a major seismic gap. Although the rupture termination of the 1999 İzmit earthquake in the east of the Sea of Marmara may constrain the eastern limit of the seismic gap [Uçarkuş et al., 2011; Gasperini et al., 2011], its western limit remains uncertain. However, a study of the 1912 earthquake sequence using seismic records and the 1912 slip distribution suggests $120-140-\mathrm{km}-$ long co-seismic rupture reaching the Central Basin in the Sea of Marmara [Aksoy, 2009; Aksoy et al., 2010], consistent with the seafloor fresh fault scarp delineation using high-resolution bathymetric data seismic and unmanned submersible observations
[Armijo et al., 2005]. The occurrence of earthquake sequences with two main shocks within a few weeks or months, similar to the 22 May and 5 August 1766, 9 August and 13 September 1912 or 17 August and 12 November 1999 sequences is another peculiarity of the earthquake faulting behavior along the western section of the NAF. Due to fault interaction, the stress change modeling indicates that the most recent seismic events caused stress accumulation in the Sea of Marmara increasing the earthquake risk for the Istanbul region [Stein et al., 1997; Hubert-Ferrari et al., 2000]. Paleoseismic investigations on the eastern section of Ganos fault close to the Sea of Marmara seismic gap appear decisive for a better seismic hazard assessment of the region.

\section{Earthquake Geomorphology and Paleoseismic Site Selection}

[17] The ENE-WSW trending Ganos fault displays a $\sim 45-\mathrm{km}$-long inland section and affects along strike pre-Neogene, Neogene and Quaternary sedimentary formations [Okay et al., 2004; Yaltırak and Alpar, 2002]. Taking into account the 1912 coseismic rupture and related slip distribution, evidence of recent tectonic movement along the fault segment can be traced continuously from the Sea of Marmara to the Saros Bay and Aegean Sea (Figures 1 and 2) [Aksoy et al., 2010]. The mapped fault, mainly delineated by 65 cumulative stream offset, including co-seismic 1912 slip, has a mean strike of $\mathrm{N} 70 \mathrm{E}^{\circ}$ and forms narrow linear valleys and geomorphic structures typical of strike slip faults (with pressure ridges, sag-ponds, step-overs, shutter-ridges and offset streams). From Gölcük region to the Saros Bay, the fault appears as linear pressure ridges before reaching the Kavak pullapart and the flat Quaternary basin of Saros. From Yörgüç to the Sea of Marmara, the fault runs along the base of the steep Ganos Mountain range and shows a complex geometry with pressure ridges damming small streams and several right and left stepping jogs (Figure 3).

[18] The collocation of cumulative slip and 1912 offset along the fault represents a helpful hint for the paleoseismic site selection along the fault. Ambraseys and Finkel [1987] report that the 1912 main shock generated surface ruptures and an average $3 \mathrm{~m}$ right-lateral slip. More systematic studies of the preserved co-seismic slip using total station and differential GPS measurements of paths and deflected streams provide right-lateral offsets ranging between 3.5 and $5.5 \mathrm{~m}$ (Figures 2 and 3) 


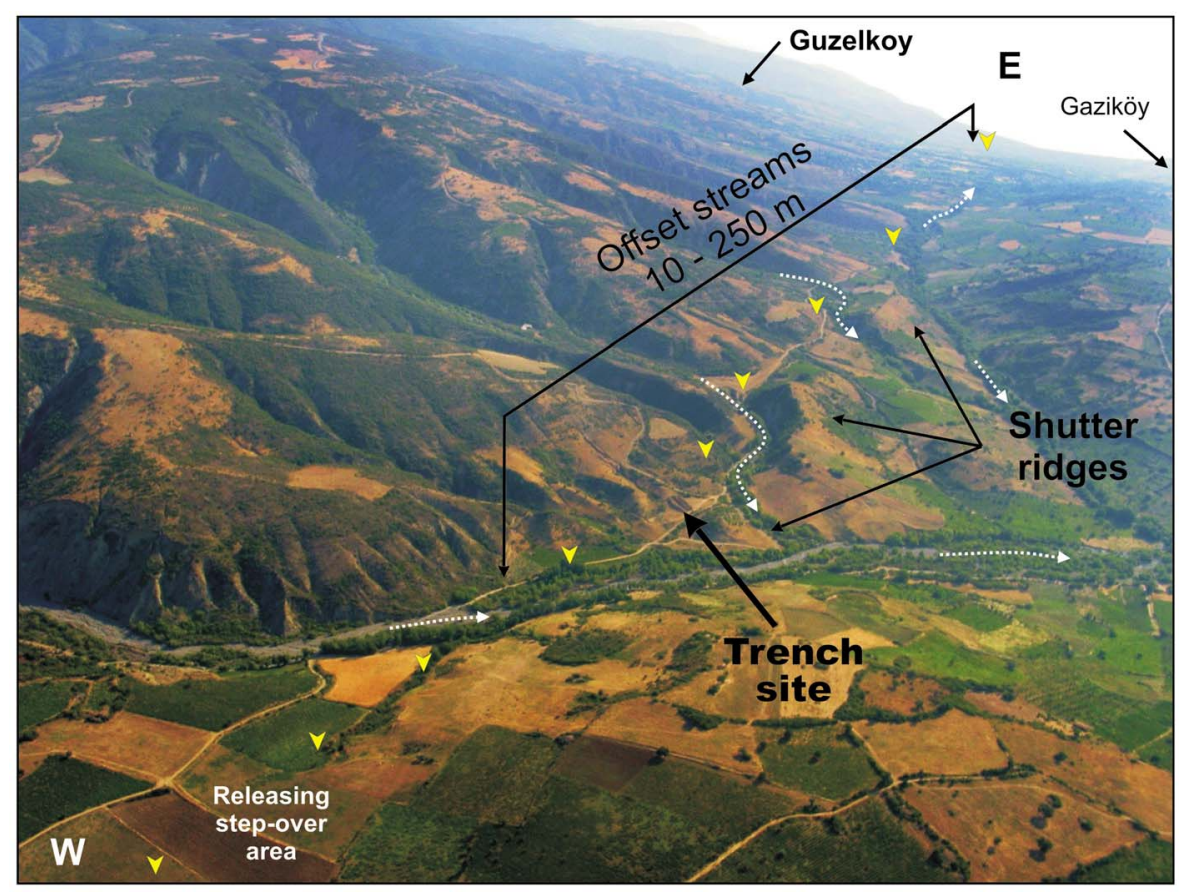

Figure 3. Perspective view (to NE) of the fault zone and the trench site (kite photograph by Stefano Pucci). The site is located on the southern flank of the Ganos Mountain with prominent stream incisions (location in Figure 2b).

[Altinok et al., 2003; Altunel et al., 2004; Aksoy et al., 2010]. Cumulative offsets of stream channel include several pre-1912 co-seismic slip, and range from 7 to more than $35 \mathrm{~m}$ (Figures 3 and 4) [Altunel et al., 2004; Aksoy, 2009]. Individual and cumulative displacements measured on stream channels are markers of successive earthquake faulting that may illustrate the characteristic slip along active faults [Schwartz and Coppersmith, 1984].

[19] The Güzelköy paleoseismic site located $\sim 5.8 \mathrm{~km}$ west of the Marmara coastline, consists of two main parallel and sporadic stream channels flowing nearly NS on $\sim 20^{\circ}$ slope upstream and $\sim 10^{\circ}$ downstream (Figures 3 and 4). The geology of the site consists of slope-waste deposits deriving from Eocene flyschs and turbidites of the southern limbs of the Ganos Mountain. The streams and related eroded material (mainly alluvial deposits and slope debris) are deflected and dammed by a $\sim 50$-m-long, ENE-WSW trending shutter ridge made of flyschs. The western stream (stream 1) shows a small deflection and incision on flat lying alluvial units. The eastern stream channel (stream 2) is on a relatively steep slope and presents a significant incision of nearby hills with an alluvial fan and a larger deflection than stream 1. Although the alluvial fan may bury geomorphological structures, the fault zone is here precisely traced from the two deviated streams and a displaced substratum ridge block of the crest in between streams (Figure 4).

[20] A micro-topographic survey with $\sim 9000$ leveled points (of channel edges and center, hill crests, flat and slope areas, and shutter ridge) has been conducted at the site using a Wild TC1800 total station (Figure 4). Data was collected with an array of $\sim 0.5 \mathrm{~m}$ (and with $\sim 0.20 \mathrm{~m}$ between leveled points along the fault zone, in channels and other geomorphic features) to document all the morphological characteristics associated with past fault movements. Channel boundaries that are well preserved in the morphology displayed an average $10.8 \mathrm{~m}$ and $21.3 \mathrm{~m}$ of cumulative right-lateral offset on stream 1 and stream 2, respectively (Figure 4). In addition, the estimated displacement of a basement block ridge provides $35.4 \pm 1.5 \mathrm{~m}$ of right-lateral cumulative slip. The adopted error range for channel and ridge offsets includes an instrumental error from the total station, the irregularity of streambed edges and an estimated projection to the fault zone. The offset uncertainties ( $\pm 0.5 \mathrm{~m}, \pm 1 \mathrm{~m}$ and $\pm 1.5 \mathrm{~m})$ are estimated from accurate total station measurements ( 1 measured point every $0.20 \mathrm{~m}$, with even closer leveled points in the fault zone and offset channels) of geomorphic features, the correlation between paleo-channel edges and bottom visible in 


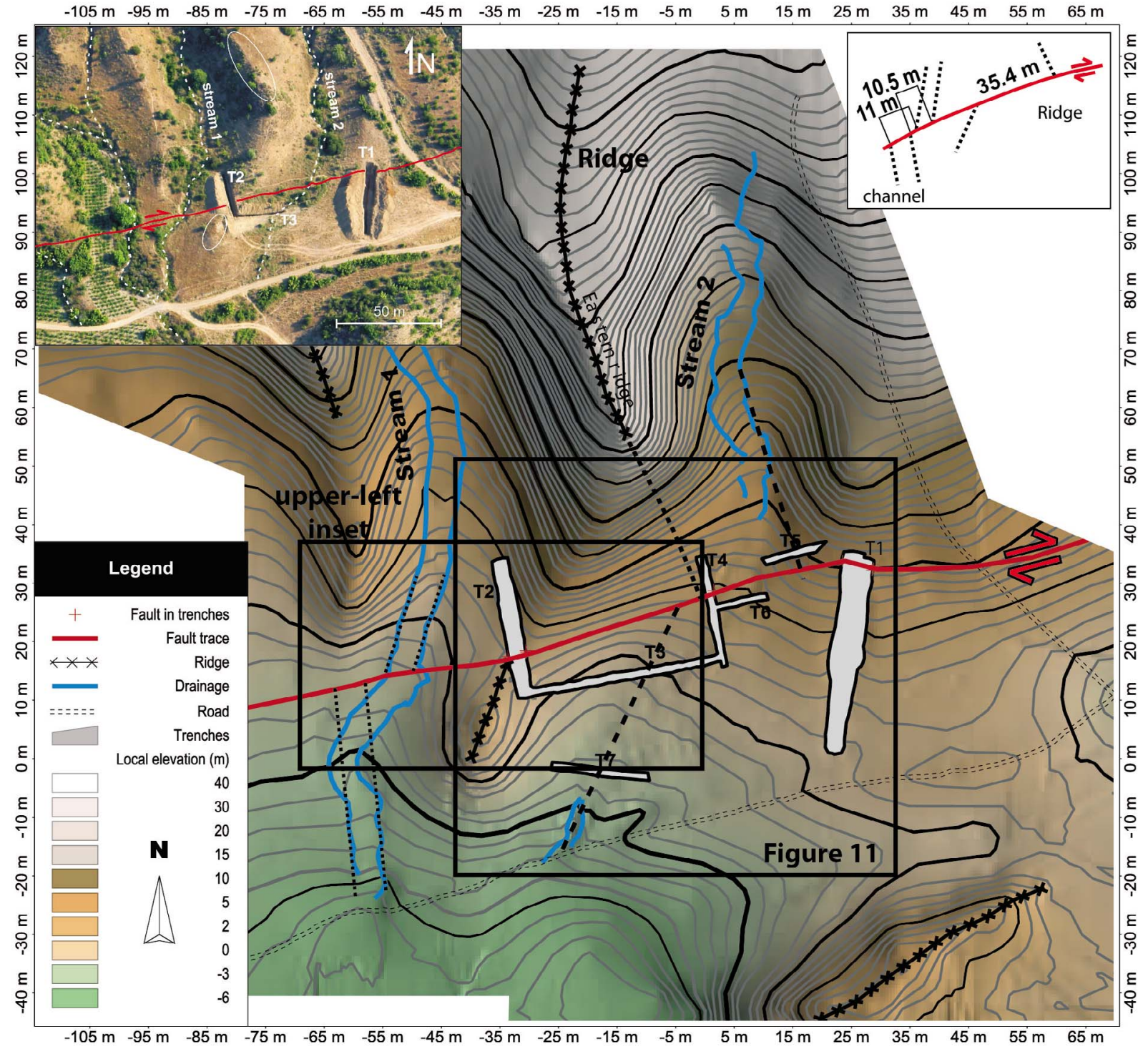

Figure 4. Microtopographic survey (thick contour line is $5 \mathrm{~m}$ obtained from $0.5 \mathrm{~m}$ to $0.2 \mathrm{~m}$ array points) of the Güzelköy site showing the location of 7 trench-excavations and their relation to the fault (location in Figures $2 \mathrm{~b}$ and 4). Upper left inset: Aerial view of the trench site and related deflected streams and offset ridge (location in Figure 2b; kite photograph by Stefano Pucci). Two cumulative offset streams are measured from the channel configurations. Using the surface morphology only, the measured stream offsets indicate $21.3 \pm 1 \mathrm{~m}$ and $10.8 \pm 0.5 \mathrm{~m}$ (for eastern and western streams, respectively) and $35.4 \pm 1.5 \mathrm{~m}$ ridge offset (see upper right inset).

trenches, and ridge block morphology, mapped on both sides of the fault. Uncertainties of fault offsets are also estimated from average distance between piercing points and geomorphic features; in most measurement of fault offsets we consider upper bounds of error bars. Taking into account the fault zone and the shutter ridge position, the stream 2 alluvial fan deposits indicate the potential for recording past successive channel offsets and well preserved paleoseismic data. The present-day erosional and depositional conditions of the site determine the three dimensional trenching scheme that enables the documentation of successive earthquake faulting and related offset.

\section{Paleoseismic Trenching}

[21] We have excavated 7 trenches near stream 2 and in between the hillslope (to the north) and the shutter ridge to the south (Figure 4). All trench walls were gridded and studied but detailed logging was performed only in one wall and selected wall sections that expose faulting structures and/or buried channel features. Each trench-wall grid was 
Table 2. Description of Stratigraphic Units in Trenches

\begin{tabular}{|c|c|}
\hline Unit & Description \\
\hline $\mathbf{a}$ & Soil $\left(=a_{1}, a_{2}\right)$ \\
\hline b & $\begin{array}{l}\text { Light, loose, sandy gravel with small } \\
\text { channels (colluvium) }\end{array}$ \\
\hline c & $\begin{array}{l}\text { Reddish colluvial wedge and stratified fine gravel } \\
\text { (colluvial wedge) }\end{array}$ \\
\hline d & $\begin{array}{l}\text { Sandy gravel with mixed light silty layers } \\
\text { (colluvial wedge) }\end{array}$ \\
\hline $\mathbf{e}_{1}$ & Light colluvial unit with clay layers (colluvium) \\
\hline $\mathbf{e}_{2}$ & Sandy clay (colluvial wedge) \\
\hline f & $\begin{array}{l}\text { Mixed sandy-silty unit alluvial fine gravel } \\
\text { (colluvium) }\end{array}$ \\
\hline g & Clasts in reddish sandy-silt \\
\hline $\mathbf{s}$ & Massive red sandy-silt with clasts \\
\hline $\mathbf{f z}$ & $\begin{array}{l}\text { Fault zone with shear fabric (oriented clasts and } \\
\text { gravel) }\end{array}$ \\
\hline $\mathbf{j}$ & $\begin{array}{l}\text { Well-sorted fine and coarse gravel unit (uppermost } \\
\text { channel deposit) }\end{array}$ \\
\hline $\mathbf{k}$ & Stratified alluvial deposit (with channels) \\
\hline \multirow[t]{2}{*}{1} & $\begin{array}{l}\mathbf{l}_{2}: \text { Coarse and fine gravels mixed with well } \\
\text { rounded pebbles }\end{array}$ \\
\hline & $\begin{array}{l}\mathbf{l}_{1} \text { : Coarse pebble and gravel typical of the base } \\
\text { of channel }\end{array}$ \\
\hline oc & Old channel unit (coarse gravels) \\
\hline $\operatorname{col}_{1}, \mathrm{col}_{2}$ & Colluvial deposit (clast in sandy-silt) in trench 5 \\
\hline $\mathbf{s}$ & Massive red sandy-silt with clasts \\
\hline $\mathbf{x}_{1}$ & Stratified coarse gravel \\
\hline $\mathbf{x}_{2}$ & Well stratified fine gravel and sandy unit \\
\hline $\mathbf{x}_{3}$ & $\begin{array}{l}\text { Fine sand and clay with small channels } \\
\text { (fine gravel) }\end{array}$ \\
\hline
\end{tabular}

leveled using total station survey to correlate the surface stream offset with the buried offset features and obtain a comprehensive view that includes trench-walls, fault zone trace and local geomorphology. Trenches T1, T2 and T4 are north-south trending, and were dug across the fault (see also Figure 6) in order to pinpoint the fault location and complement micro-topography and stream deflections, and study the repeated fault movements and their relation to colluvial wedges. Trenches T3, T5, T6 and T7 are ENE-WSW to E-W trending and dug parallel to the fault zone in order to study the stream channel deposits and deflection and their relation to the successive fault movements. All trenches display coarse to fine alluvial sedimentary units and slope debris material that provide the potential for recording the successive earthquake faulting. We describe here below and in Table 2 the stratigraphic layers of alluvial and slope deposits for both the crosscutting and parallel trenches.

\subsection{The Stratigraphic Succession}

[22] Trench 1 was dug on the left bank of stream 2 and across a small scarp that may correspond to the
1912 rupture. The trench is $35-\mathrm{m}$-long and deep enough to reveal a $\sim 5$-m thick succession of alluvial coarse, fine gravels and sandy silty units. Trench 1 revealed a complex fault zone with several rupture branches and associated colluvial deposits (Figure 5a). The detailed logging of the northern trench section close to the fault reveal a massive red sandy-silt deposit with clasts (unit $s$ in Figure 5a) lying on a white sandy clay (unit $\boldsymbol{w}$ in Figure 5b) visible at the trench bottom and north of the fault zone. South of the fault zone, unit $\boldsymbol{g}$, made of clasts in reddish sandy-silt, covers unit $s$ and corresponds to a minimum 1-m-thick colluvial deposit with a matrix of probably re-worked material deriving from unit $\boldsymbol{s}$. Units $\boldsymbol{a}, \boldsymbol{c}$ and $\boldsymbol{d}$ made of stratified fine gravels, sandy gravels with mixed light silty layers (Table 1), correspond to colluvial wedges with less than $0.5 \mathrm{~m}$ thickness near the fault zone and may result from fault scarp degradation. Units $\boldsymbol{b}, \boldsymbol{e}$ and $\boldsymbol{f}$ are colluvial deposits made of sandy gravel mixed with alluvial deposit (small channels) and with 0.2 to $0.5-\mathrm{m}$ constant thickness across the fault zone. Unit $\boldsymbol{e}$ composed of clay layers overlain by colluvial deposits made of sandy-clay mixed with fine gravels, shows some materials within the fault zone. Unit $\boldsymbol{f}$ is made of colluvial deposits mixed with sandy-silty layers containing alluvial fine gravel and channel structures downslope. The succession of colluvial units that appears next to the fault zone illustrates the previous faulting episodes.

[23] Trench T2, 25-m-long and located across the fault, between the displaced basement block and the hillslope (Figure 4). The trench log of Figure 6 shows unit $\boldsymbol{s}$ (massive red sandy-silt, similar facies of the unit in trench T1) north of the fault zone; south of the fault zone, a 1.5-m-thick pond deposits (fine and laminated silty-clay layers, unit $\boldsymbol{x} 3$ ) overlay unit $\boldsymbol{x} \mathbf{2}$, made of laminated sandyclay with intercalated coarse gravels and unit $\boldsymbol{x} \mathbf{1}$ with well stratified coarse alluvial deposits (Figure 6). Unit $\boldsymbol{x} 3$ is overlain by unit $\boldsymbol{d}$, a $\sim 0.1$ m-thick laminated light clay that ends the pond sedimentation. These deposits rapidly wedge-out near the main fault zone and further south across a secondary fault; this suggests a tectonic control of sedimentation on a small pull-apart basin. The stratigraphic succession continues with unit $c$, made of stratified fine gravel, laying conformably on unit $\boldsymbol{x} \mathbf{3}$ and both units show a significant northward tilting $\left(\sim 20^{\circ}\right)$ toward the nearby main fault zone $(f z$ in Figure 6). Unit $\boldsymbol{b}$ consists of loose sandy gravels with small channels and covers unconformably units $\boldsymbol{x} \mathbf{3}, \boldsymbol{d}$ and $\boldsymbol{c}$. The fault zone is here $\sim 4 \mathrm{~m}$ wide 
(a)

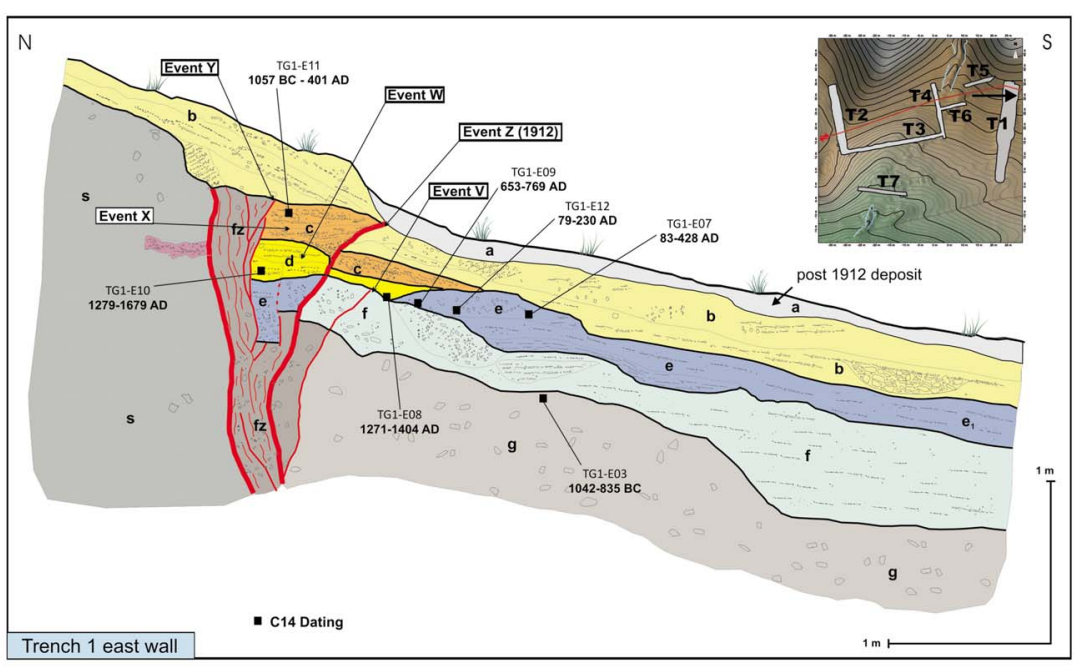

(b)

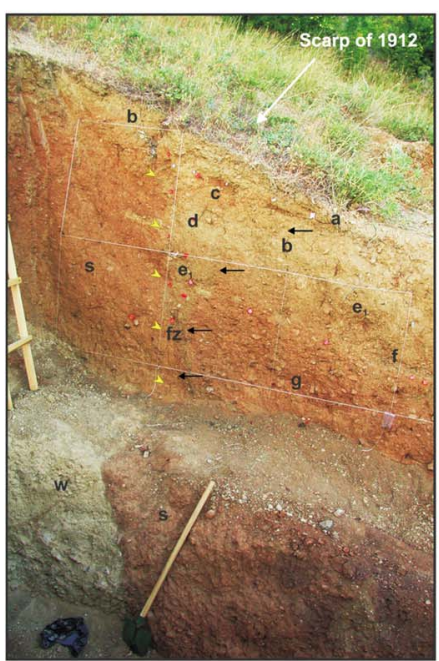

Figure 5. (a) East wall of trench $\mathrm{T} 1$ across the fault zone (inset showing the trench and arrow the logged wall section). The exposed fault shows 0.5 to $1 \mathrm{~m}$-wide-rupture zone (red lines) located below a prominent scarp observed at the surface. The succession of colluvial wedges illustrates the faulting events (V, W, X, Y and Z; see Table 2 and text for unit descriptions). The location of collected detrital charcoal samples and dating results are also reported in Table 3. (b) Fault zone (yellow and black arrows) in trench T1 (east wall) pointed out by the sharp contact between unit $g$ and unit $s$, that extends upward within colluvial wedges (see also trench log in Figure 5a). The surface topography and recent colluvium $\boldsymbol{a}$ suggest $\sim 0.5 \mathrm{~m}$ vertical component of 1912 coseismic offset. The substratum unit $\boldsymbol{s}$ exhibits a significant vertical offset of the northern block in agreement with the 1912 faulting at this site.

and consists of the main fault zone $f z$ and several branches affecting alluvial and lacustrine deposits (unit $\boldsymbol{x 3}$ ). Because T2 is in between the two ridge blocks at a high level topography, its stratigraphy is comparable to $\mathrm{T} 1$ but different from other trenches located within the alluvial fan deposits of the eastern stream. At the southern end of the trench, unit $\boldsymbol{x} \mathbf{1}$ of T2 is overlain by unit $\boldsymbol{g}$ of T3.

[24] Trenches T3 to T7 display channel structures (Figure 4). Trench T3 is 40-m-long parallel and close $(5-10 \mathrm{~m})$ to the fault; it connects T4 with T2

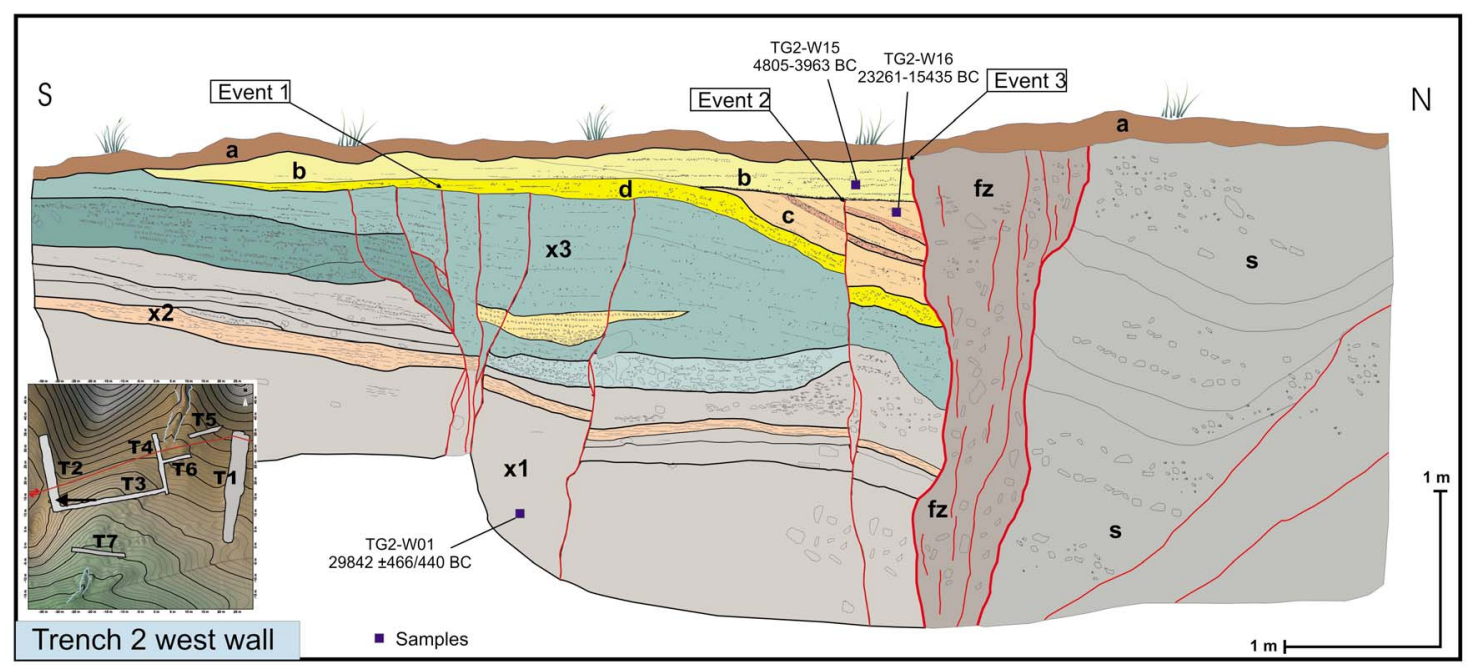

Figure 6. West wall of trench T2 across the fault zone (inset showing the trench and arrow the logged wall section). The 0.5 to $1 \mathrm{~m}$-wide-fault zone below unit $\boldsymbol{a}$ limits to the north a succession of fine lacustrine sediments overlaying fine and coarse gravel units (see Table 2 for description). Other fault branches also affect the sedimentary units and uppermost layers below units $\boldsymbol{b}$ and $\boldsymbol{d}$ (see text for explanation). Radiocarbon dating of three charcoal samples is also indicated in Table 3. Three faulting events older than older than unit $b$ can be identified in this trench exposure. 

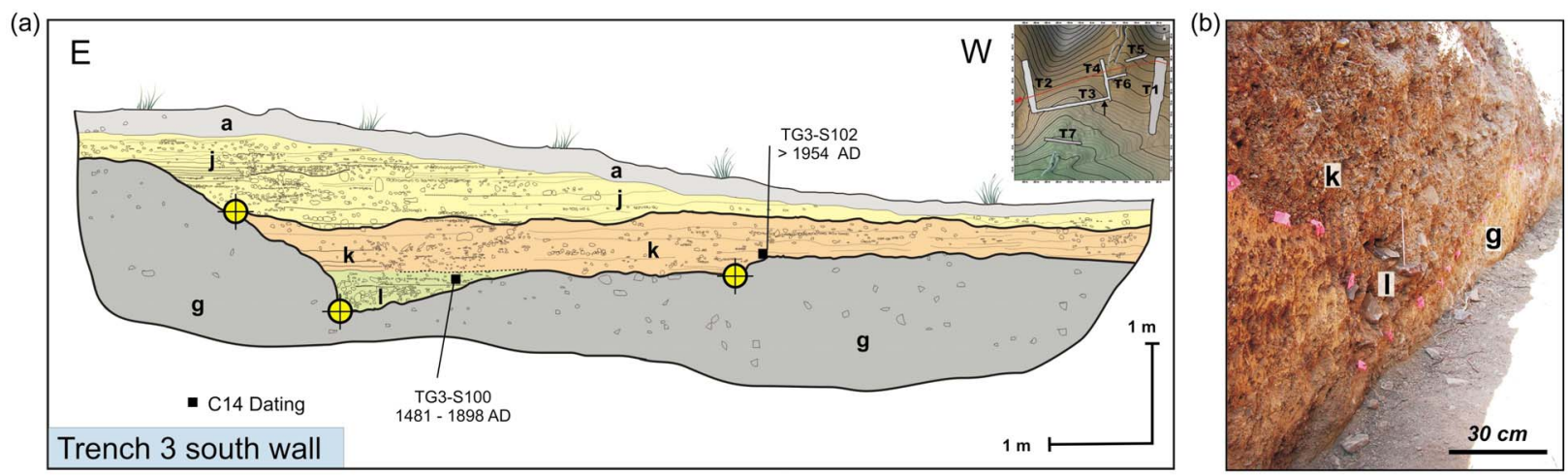

Figure 7. (a) South wall section of trench T3 parallel to the fault zone and exposing an asymmetric buried channel with a succession of three main alluvial deposits (inset showing the trench and arrow the logged wall section). Dating results of two charcoal samples are also indicated in Table 3. Yellow circles are total station survey points of main channel geometry. (b) The asymmetric buried channel of trench T3 is pointed out by a sharp erosive surface on the substratum (pink flags).

and displays a sharp unconformity of a buried channel on the massive red sandy silt (unit $g$ in Figure 7). We have focused the detailed trench logging on the eastern section where a clear buried channel and alluvial units are exposed. The paleochannel is asymmetric (deepest units close to the east) and shows a succession of coarse gravels at the base (unit $\boldsymbol{l}$, Figure 7a) overlain by well-sorted fine and coarse gravel layers (unit $\boldsymbol{k}$ ) and fine gravels mixed with sandy layers of overlapping small channels (unit $\boldsymbol{j}$ ). Trench T4 is $\sim 20$-m-long, also dug across the fault, and shows a $\sim 2$-m-thick well-sorted fine and coarse gravel deposits mixed with sandy layers of small channels (unit $\boldsymbol{j}$ ) overlapping the massive red sandy-silt (unit $\boldsymbol{g}$, Figure 8a). The fault sharply limits the massive red sandy-silt deposit with clasts of unit $s$ to the north from $\sim 1-\mathrm{m}-$ thick fine gravel unit $\boldsymbol{j}$ to the south (also visible in trench T6). Below unit $\boldsymbol{j}$, the well-sorted fine and coarse gravel layers of unit $\boldsymbol{k}, \sim 0.5$-m-thick, overlay the coarse gravels of unit $\boldsymbol{l}$. Fault branches visible at the trench base are overlain by unit $\boldsymbol{l}$. At the top of trench wall, the fault zone is buried by young channel deposits. The correlation between T3 and $\mathrm{T} 4$ shows a similar basement unit $\boldsymbol{g}$ and a similar unit $\boldsymbol{j}$ with comparable thickness; the uppermost unit a shows a different thickness from $\sim 0.5 \mathrm{~m}$ in $\mathrm{T} 4$ to $0.2 \mathrm{~m}$ in T3 likely due to irregularities in the alluvial fan deposits.

[25] Trench T5 is $\sim 13-\mathrm{m}-$ long, and the only faultparallel excavation located on the northern fault compartment (Figure 4). Field observations on the left bank alluvial terrace and related coarse pebble and gravel led us to infer the existence of a buried channel east of the stream. In fact, trench $\log$ of Figure $8 \mathrm{~b}$ shows a paleo-channel with coarse gravels at the base (unit $l$ ) and stratified, wellsorted fine and coarse gravels (unit $\boldsymbol{k}$ ) and fine gravels mixed with sandy layers of small channels (unit $\boldsymbol{j}$ ). Unit $\mathrm{j}$ overlays colluvial unit $\boldsymbol{c o l}_{\mathbf{1}}$ and interfingers with colluvial unit $\boldsymbol{c o l}_{2}$. The main channel incises the red sandy-silt deposit with clasts (unit $\boldsymbol{s}$ ) and is overlain by a succession of colluvial deposits that also cover an old and perched alluvial unit co. Trench T6 is also parallel to the fault but dug immediately south $(\sim 3 \mathrm{~m})$ of the fault as traced from T1, T2 and T4 (Figure 4). The trench exhibits a succession of $\sim 1.5$-m-thick paleochannel deposits incising the massive red sandy-silt deposit with clasts (unit $g$, Figure 8c). Within the channel, the lowermost deposit is made of coarse gravel and pebble (unit $l$ ) overlain by well-sorted fine and coarse gravels (unit $\boldsymbol{k}$ ). On the top, unit $\boldsymbol{j}$ made of fine gravels mixed with sandy layers of small channels truncates considerably units $\boldsymbol{g}$ and $\boldsymbol{k}$. Trench T6 is $\sim 8-\mathrm{m}-$ long, orthogonal to the fault strike and intersects T4 with unit $\boldsymbol{j}$ visible in both trenches. Looking to the easternmost edge of the alluvial fan, T6 was also dug proceeding eastward beginning from $\mathrm{T} 4$ in order to meet the edge of alluvial deposits and channel and related unit $\boldsymbol{g}$ below (Figures 4, 8 and 10). The geometry of channels, as deduced from both walls of trenches T3, T4 and T6, suggests the existence of at least two parallel channels and related alluvial fans also indicated by units $\boldsymbol{l}, \boldsymbol{k}$ overlapped by unit $\boldsymbol{j}$. Our aim was here to compare channel deposits and related offset of eastern edges between channels in T3, T4, T5 and T6 (Figures 7, 9 and 10).

[26] Trench T7 is $\sim 16-\mathrm{m}$-long dug sub-parallel to the fault but at approximately $20 \mathrm{~m}$ south to the fault with the aim of revealing the southernmost 
(a)

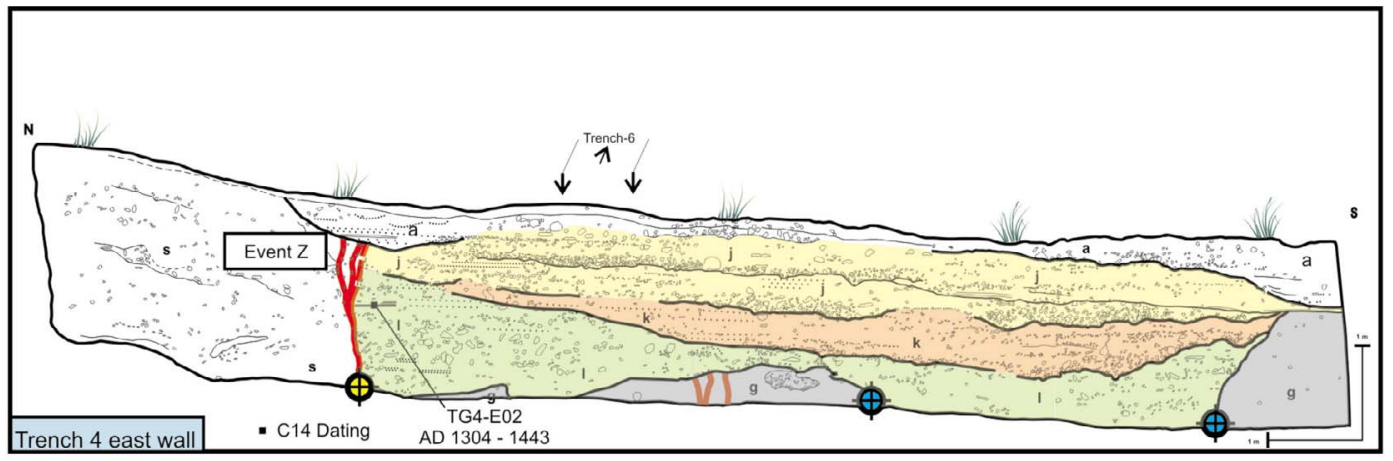

(b)

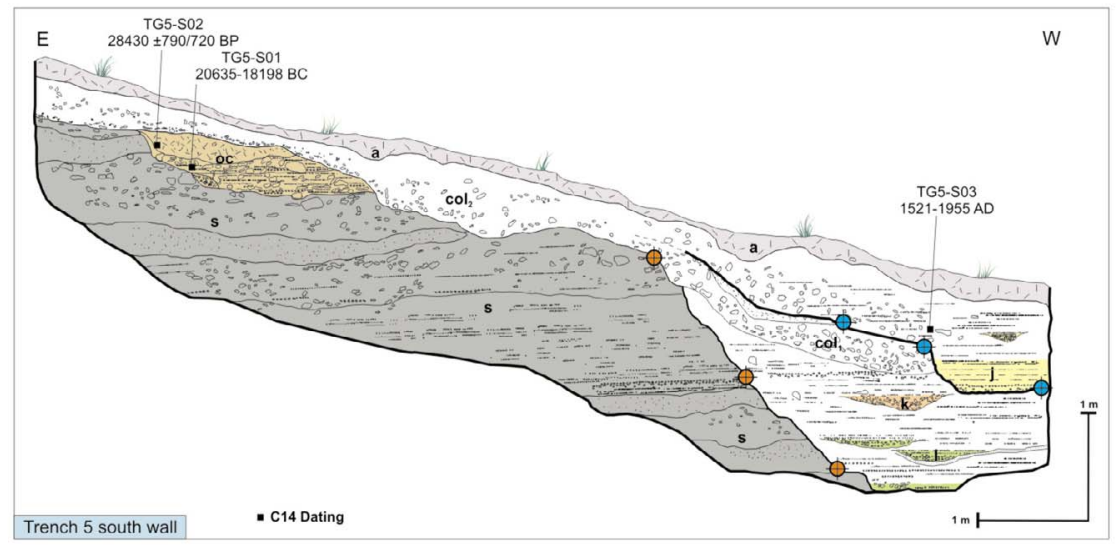

(c)

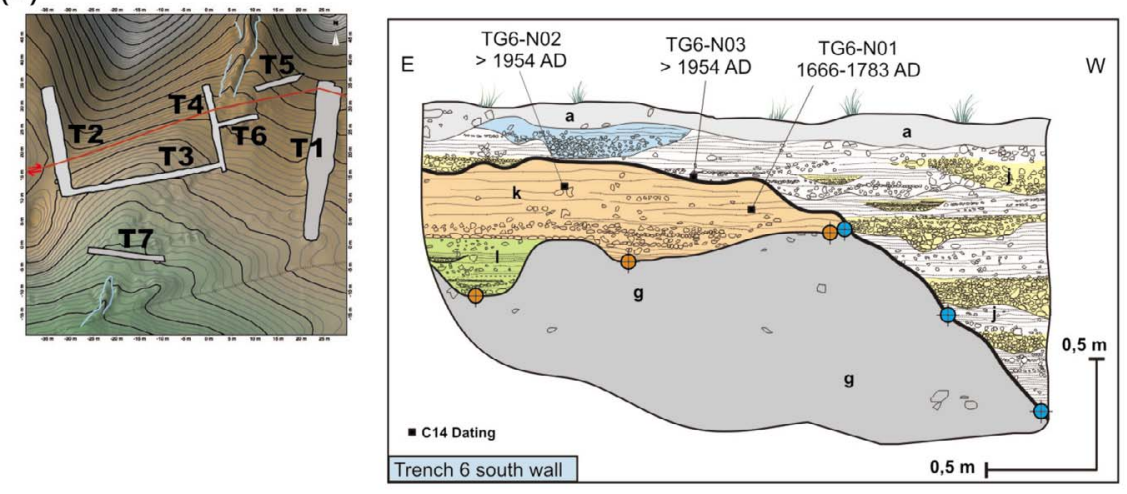

(d)

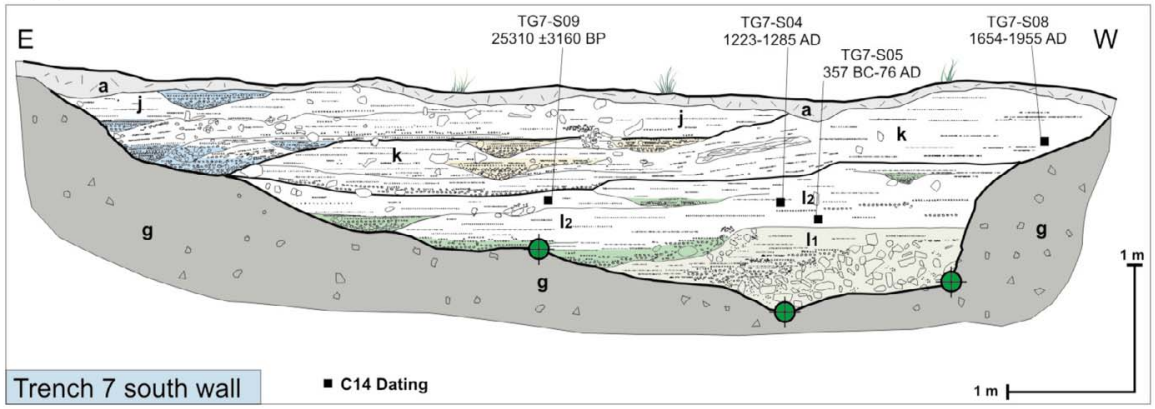

Figure 8 
buried channel structure and compare it with the estimated total cumulative channel offset visible at the surface (Figure 4). The trench wall exposes an impressive $\sim 1.5$-m-thick paleo-channel structure that incises the massive red sandy-silt deposit with clasts (unit $g$, Figure 8d). In the channel, the lowermost deposit $\boldsymbol{l}_{\mathbf{1}}$ shows coarse pebble and gravel typical of the base of channel deposits; $\boldsymbol{l}_{2}$ is made of coarse and fine gravels mixed with well rounded pebbles overlain by $\sim 0.50$-m-thick unit $\boldsymbol{k}$ showing stratified fine gravels and sandy layers. Unit $\boldsymbol{k}$ is truncated by unit $\boldsymbol{j}$ that is made of numerous small channel structures with well sorted fine gravels also mixed with sandy layers. The overall channel structure shows a significant asymmetry, with the deeper incision toward west.

\subsection{Paleoearthquake Analysis and Faulting Events}

[27] The paleoseismic study aimed here to correlate the successive earthquake faulting in crosscutting trenches with the right-lateral offset observed from deflected stream channels. The timing of successive faulting episodes is constrained using 25 dated samples of charcoal fragments and organic-rich bulk sediments. Table 3 shows the analytical characteristics of samples, their corresponding unit in Figures 5 to 11 , and radiocarbon dates. All radiocarbon dates (Table 3) are $2 \sigma$ calibrated using Oxcal v4.0 [Bronk Ramsey, 2009] software and INTCAL04 calibration curve of Reimer et al. [2009].

[28] Trench T1 shows near the surface the most recent faulting event and fault scarp that may likely correspond to the surface rupture of the 9 August
1912 earthquake (see thick fault lines in Figure 5a and yellow and black arrows in Figure 5b). The shear zone is $\sim 0.5$-m-wide is formed by several fault branches arranged as a "positive flower structure." This structure marks transpressive deformation and shows several fault branches representing a transpressive faulting geometry. The trench $\log$ reveals the succession of colluvial wedge units $\boldsymbol{d}$ and $\boldsymbol{c}$ next to the fault zone resulting from past surface rupturing events, similarly to unit $\boldsymbol{a}$ that postdate the 1912 earthquake. Indeed, the surface topography and recent colluvium $\boldsymbol{a}$ on the trench wall in Figure $5 \mathrm{~b}$ suggest $\sim 0.5 \mathrm{~m}$ vertical component of the 1912 coseismic offset. Colluvial unit $\boldsymbol{b}$, made of light loose sandy gravel mixed downslope with alluvial deposit (small channels), truncates previous deposits and shows $\sim 0.25 \mathrm{~m}$ vertical separation on the fault, which can be correlated with event Z (1912 earthquake). Unit $c$ is a reddish colluvial wedge with sorted fine gravels faulted by event $\mathrm{Y}$ and buried by unit $\boldsymbol{b}$. The timing of event $\mathrm{Y}$ is difficult to infer because of the probably reworked detrital charcoal present in sample TG1-E11 and related old age (BC 1057 $\mathrm{AD} 401$, Table 3). The erosion of an earlier earthquake fault scarp, related to event $\mathrm{X}$, forms the deposition of unit $\boldsymbol{c}$. Unit $\boldsymbol{d}$ made of well stratified sandy gravels mixed with colluvium and light silty layers provides two consistent radiocarbon ages AD 1271-1404 and AD 1279-1679 that predate events $\mathrm{X}, \mathrm{Y}$ and $\mathrm{Z}$. Unit $\boldsymbol{d}$, which has a distinct texture and color, may result from fault scarp degradation associated with another faulting event W, that affects unit $\boldsymbol{e}$. Below unit $\boldsymbol{d}$, unit $\boldsymbol{e}$ corresponds to a colluvial wedge deposit visible within the fault zone at $1 \mathrm{~m}$ further south. The colluvial

\footnotetext{
Figure 8. Trenches T4, T5, T6 and T7 of the Güzelköy paleoseismic site. (a) East wall of trench T4 showing a $\sim 2$-m-thick alluvial fan deposits (units $\boldsymbol{l}, \boldsymbol{k}, \boldsymbol{j}, \boldsymbol{b}$ and $\boldsymbol{a}$ ) limited to the north by the fault zone overlain by unit $\boldsymbol{a}$. Although the trench exposure is parallel to the alluvial fan, the inner fan stratigraphy and geometry indicate two successive channels (unit $\boldsymbol{j}$ overlapping units $\boldsymbol{k}$ and $\boldsymbol{l}$ ) also visible in trench T6 (Figure 8c). Dating results of one charcoal sample on east wall and two charcoal samples TG4-W01 and TG4-W03 on west wall are indicated in Table 3; the faulting event is younger than unit $\boldsymbol{a}$ and may correspond to event Z. Yellow and blue circles are total station survey points of main channel geometry (see also Figure 11). (b) South wall of trench T5 north of the fault zone. The exposure displays a sharp channel incision with successive alluvial deposits made of units $\boldsymbol{j}, \boldsymbol{k}$ and $\boldsymbol{l}$ (see Table 1 for description). The old alluvial unit $\boldsymbol{o c}$ marks the location an old uplifted channel deposit. Channel $\mathrm{j}$ which is lying on colluvial units $\left(\boldsymbol{c o l}_{\mathbf{1}}\right)$ overlaps channel units $\boldsymbol{k}$ and $\boldsymbol{l}$. Dating results of three charcoal samples are also indicated in Table 3. Orange and blue circles are total station survey points of main channel geometry (see also Figure 11). (c) South wall of Trench T6 is immediately south and parallel to the fault trace. The exposure exhibits two successive channel incisions with unit $\boldsymbol{j}$ overlapping units $\boldsymbol{k}$ and $\boldsymbol{l}$ (in direct continuation of trench T4). The deposit in blue is a detail of a young channel below unit a. Dating results of three charcoal samples are indicated in Table 3. Orange and blue circles are total station survey points of main channel geometry (see also Figure 11). (d) South wall of trench T7 located further south from the fault zone. It shows an asymmetric geometry with a succession of eastward overlapping channels. Dating results of four charcoal samples are indicated in Table 3. We observe that sample TG7-S09 $(25319 \pm 3160 \mathrm{BP})$ is out of sequence with respect to the three other radiocarbon dating. Orange and blue circles are total station survey points of main channel geometry (see also Figure 11).
} 


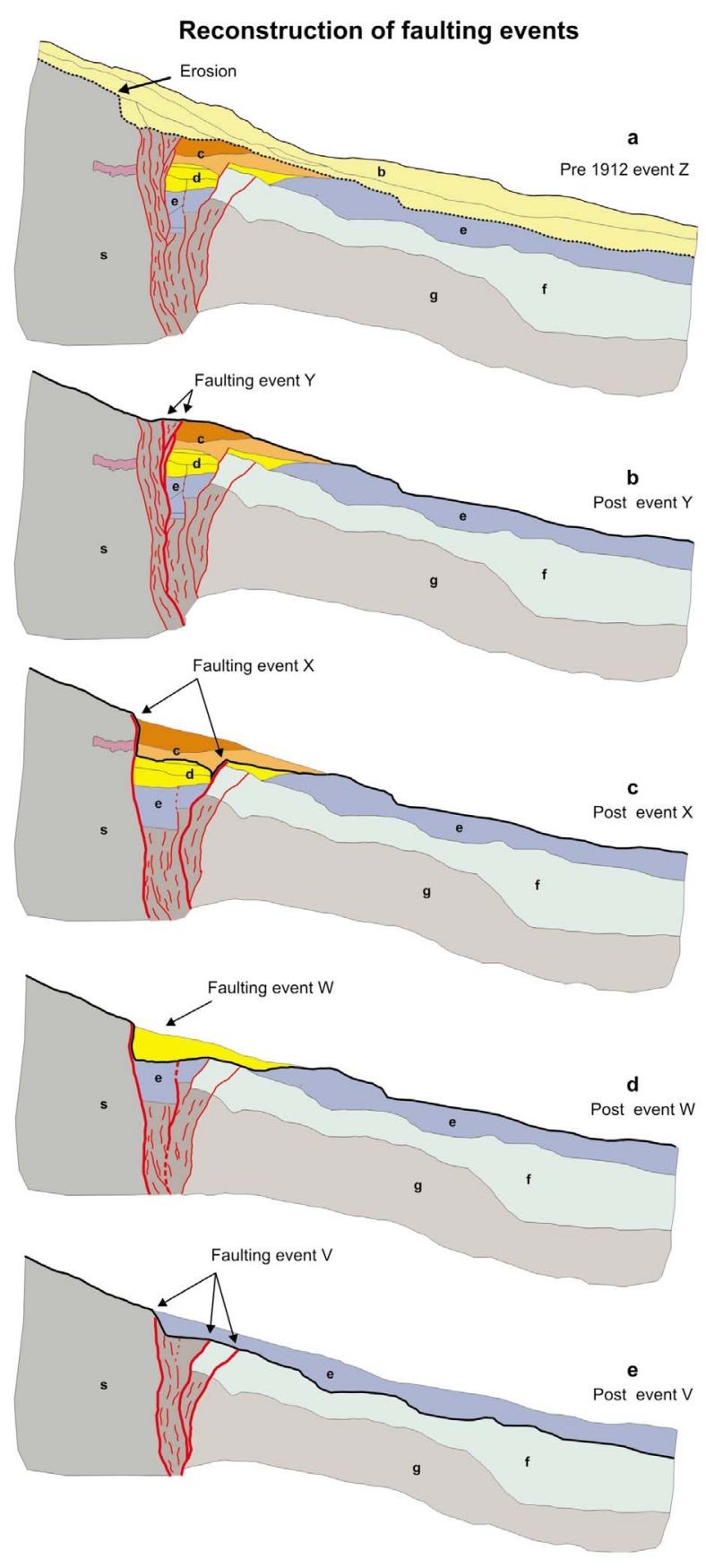

Figure 9. Reconstruction of trench T1 faulting events (pre-1912) based on vertical separations of sedimentary units, colluvial wedges (units e, $\mathrm{d}$ and $\mathrm{c}$ ) and colluviums (units $\mathrm{f}$, e and b). See also text for explanation. Unit o is inferred to be a colluvial wedge of event $Y$ that is subsequently eroded as indicated from a distinct erosion surface below unit $b$. The reconstruction suggests the occurrence of five faulting events $\mathrm{V}, \mathrm{W}, \mathrm{X}, \mathrm{Y}$ and $\mathrm{Z}$ at this site along the Ganos segment of the NAF (see also Table 4). Event $Z$ corresponds to the faulting of unit $b$ visible in the log of trench T1 (Figures 5a and 5b). wedge $\boldsymbol{e}$ results from the erosion of a fault scarp associated with faulting event $\mathrm{V}$. The uppermost layers of $\boldsymbol{e}$ provide three consistent $\mathrm{C}^{14}$ ages AD 79-230 and AD 83-428 and AD 653-769 that predate faulting event $\mathrm{W}$ and postdate event $\mathrm{V}$. Colluvial units $\boldsymbol{f}$ and $\boldsymbol{e}$ are comparable to unit $\boldsymbol{b}$ and their constant thickness across the fault indicates that they do not result from fault scarp degradation. Although the erosional surface between units $\boldsymbol{f}$ and $g$ may also indicate the probable occurrence of a significant sedimentary truncation that could have erased the earthquake record, the uppermost layers of unit $\boldsymbol{g}$ provides the radiocarbon age BC 1042835 , also predating past faulting events indentified in trench T1. The substratum unit $s$ exhibits a significant vertical offset $>2 \mathrm{~m}$ (the base of $\boldsymbol{s}$ being not reached) showing an uplifted northern block in agreement with the 1912 fault scarp.

[29] A straightforward result of the paleoearthquake timing from trench $\mathrm{T} 1$ is the occurrence of five faulting events $\mathrm{V}, \mathrm{W}, \mathrm{X}, \mathrm{Y}$ and $\mathrm{Z}$ and related faulted colluvial deposits $\boldsymbol{e}, \boldsymbol{d}, \boldsymbol{c}, \boldsymbol{o}$ and $\boldsymbol{a}$ (Table 4 and Figure 9). Unit $\boldsymbol{o}$ that is not visible in T1 (because it is completely eroded) is here inferred from the reconstruction of Figure 9 as the colluvial deposit that results from the erosion of fault scarp event $\mathrm{Y}$ is truncated by unit $\mathrm{b}$. The faulting events are inferred from the successive subtraction of fault slip and related colluvial units. In this reconstruction, however, we take into account that the alluvial and colluvial units thicknesses, distribution and contact with fault branches can vary because of the lateral component of faulting. Therefore, illustrations are partly schematic and aim to correlate in 2-dimension faulting events and related colluvial wedges. Beginning from the most recent event, we suggest the following steps (as shown in Figure 9):

[30] 1. 1912 (Figure 9a): The fault structure indicates transpressive geometry (mole track), displacing unit $\mathrm{b}$ with $\sim 0.25 \mathrm{~m}$ vertical separation.

[31] 2. Event Y (Figure 9b): The transpressive rupture zone is thrusting unit $c$. The fault affects units $\boldsymbol{e}, \boldsymbol{d}$ and $\boldsymbol{c}$. The resulting surface warping combined with erosion and truncation by unit $b$ may explain why there is no colluvial wedge unit $\boldsymbol{o}$ related to this event. The vertical separation cannot be estimated because the top of unit $c$ is also truncated.

[32] 3. Event X (Figure 9c): The surface rupture forms a prominent scarp and its erosion allows deposition of colluvial wedge $c$. We may here estimate a minimum $0.40 \mathrm{~m}$ vertical slip comparable 


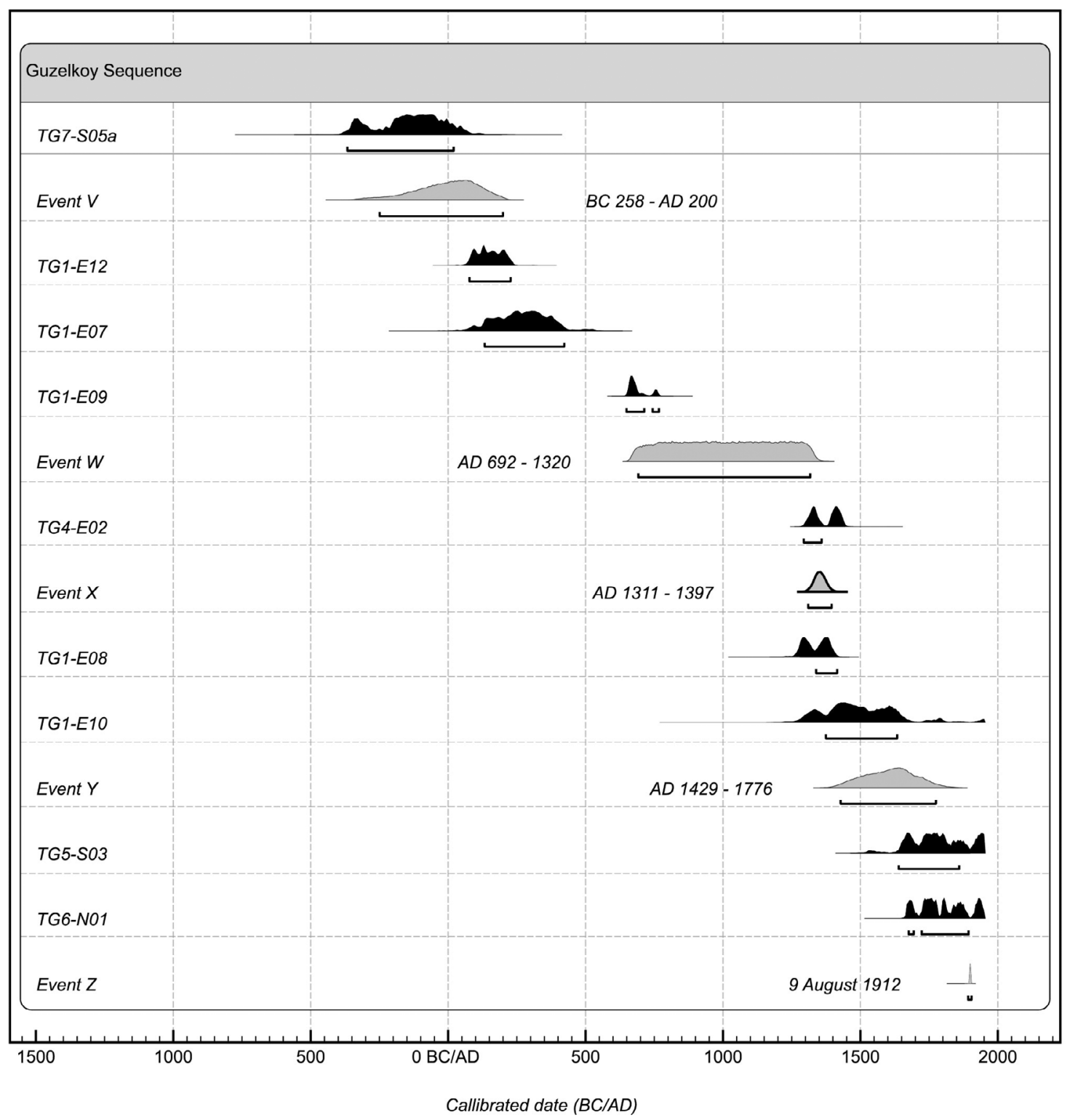

Figure 10. Timing of past earthquakes from the reconstruction of Figure 9 and estimated age of right-lateral offset from trenches T3, T4, T5, T6 and T7. Dated samples (see also Table 3) with $2 \sigma$ age range and $94.5 \%$ probability using calibration curve INTCAL09 from Reimer et al. [2009] and sequential distribution of the samples and events. The Oxcal program [Bronk Ramsey, 2009] (http://c14.arch.ox.ac.uk/oxcalhelp/hlp_analysis_detail.html) simulates the time range of faulting events $\mathrm{V}, \mathrm{W}, \mathrm{X}$, and Y based on the Bayesian distribution with event Z known as the 1912 earthquake.

to the thickness of unit $c$. Although faulting of unit $\boldsymbol{d}$ may show normal rupture geometry, this apparent structural feature can be due to the lateral slip and variable unit thickness along the fault.

[33] 4. Event W (Figure 9d): The fault scarp allows deposition of colluvial wedge $\boldsymbol{d}$. Taking into account the erosion of top layers, we estimate $\sim 0.30 \mathrm{~m}$ minimum vertical slip from the thickness of unit $\boldsymbol{d}$.
[34] 5. Event V (Figure 9e): The fault rupture affects unit $\boldsymbol{f}$ forms a scarp that is subsequently eroded and allows deposition of colluvial wedge $\boldsymbol{e}$. We estimate $\sim 0.40$ minimum vertical slip comparable to the thickness of unit $\boldsymbol{e}$. The dating of young colluvial deposit $\boldsymbol{e}$ in trench $\mathrm{T} 1$ suggests the occurrence of four faulting events $\mathrm{W}, \mathrm{X}, \mathrm{Y}$ and $\mathrm{Z}$ starting from the calibrated age AD 79-769 (Table 3 and Figures 5a and 9). A lowerbound of event $\mathrm{V}$ is suggested by the uppermost layers of unit $\boldsymbol{g}$ dated BC 1042-835. However, event V is 
Table 3. $C^{14}$ Dating of Samples From All Trenches ${ }^{\mathrm{a}}$

\begin{tabular}{|c|c|c|c|c|c|c|c|}
\hline \multirow{2}{*}{$\frac{\text { Sample Name }}{\text { TG1-E03 }}$} & \multirow{2}{*}{$\begin{array}{c}\begin{array}{c}\text { Trench } \\
\text { Unit }\end{array} \\
\mathrm{G}\end{array}$} & \multirow{2}{*}{$\begin{array}{c}\text { Amount of } \\
\text { Carbon (mg) } \\
3,77\end{array}$} & \multirow{2}{*}{$\frac{\mathrm{d} 13 \mathrm{C}(\%)}{-24,72}$} & \multirow{2}{*}{$\begin{array}{c}\text { Radiocarbon } \\
\text { Age (BP) } \\
2802\end{array}$} & \multirow{2}{*}{$\begin{array}{c}\begin{array}{c}\text { Uncertainty } \\
( \pm \text { years })\end{array} \\
39\end{array}$} & \multicolumn{2}{|c|}{$\begin{array}{c}\text { Calibrated Age } \\
(+=\mathrm{AD}) 2 \sigma \text { Range }\end{array}$} \\
\hline & & & & & & -1042 & -835 \\
\hline TG1-E07 & $\mathrm{E}$ & 0,24 & $-24,18$ & 1760 & 75 & 83 & 428 \\
\hline TG1-E08 & $\mathrm{D}$ & 0,3 & $-32,75$ & 660 & 55 & 1271 & 1404 \\
\hline TG1-E09 & $\mathrm{E}$ & 1,34 & $-24,09$ & 1330 & 25 & 653 & 769 \\
\hline TG1-E10 & $\mathrm{D}$ & 0,1 & $-34,88$ & 450 & $+140 /-130$ & 1279 & 1679 \\
\hline TG1-E11 & $\mathrm{C}$ & 0,05 & $-30,51$ & 2290 & $+310 /-300$ & -1057 & 401 \\
\hline TG1-E12 & $\mathrm{E}$ & 3,47 & $-24,9$ & 1865 & 30 & 79 & 230 \\
\hline TG2-W01 & $\mathrm{x} 1$ & 1,26 & $-22,56$ & 29840 & $+470 /-440$ & - & - \\
\hline TG2-W15 & $\mathrm{B}$ & 0,13 & $-24,57$ & 5550 & 200 & -4805 & -3963 \\
\hline TG2-W16 & $\mathrm{C}$ & 0,08 & $-24,33$ & 17700 & $+1580 /-1320$ & -23261 & -15435 \\
\hline TG3-S100 & $\mathrm{L}$ & 0,32 & $-25,35$ & 235 & 60 & 1481 & 1898 \\
\hline TG3-S102 & $\mathrm{K}$ & 0,19 & $-25,99$ & modern & - & - & - \\
\hline TG4-E02 & $\mathrm{L}$ & 0,3 & $-29,69$ & 535 & 45 & 1304 & 1443 \\
\hline TG4-W01 & $\mathrm{K}$ & 5,7 & $-24,79$ & 345 & 20 & 1480 & 1635 \\
\hline TG4-W03 & $\mathrm{J}$ & 0,69 & $-24,59$ & 1720 & 70 & 130 & 524 \\
\hline TG5-S01 & $\mathrm{Oc}$ & 0,27 & $-29,74$ & 17960 & $+440 /-420$ & -20635 & -18198 \\
\hline TG5-S02 & $\mathrm{Oc}$ & 0,58 & $-25,03$ & 28430 & $+790 /-720$ & - & - \\
\hline TG5-S03 & $\mathrm{J}$ & 0,24 & $-25,95$ & 180 & 60 & 1521 & 1955 \\
\hline TG6-N01 & $\mathrm{K}$ & 1,3 & $-22,87$ & 155 & 30 & 1666 & 1783 \\
\hline TG6-N02 & $\mathrm{K}$ & 0,1 & $-31,30$ & modern & - & - & - \\
\hline TG6-N03 & $\mathrm{J}$ & 0,45 & $-29,55$ & modern & - & - & - \\
\hline TG7-S04 & $\mathrm{L}$ & 5,0 & $-25,13$ & 765 & 20 & 1223 & 1285 \\
\hline TG7-S05 & $\mathrm{L}$ & 0,3 & $-28,67$ & 2080 & 80 & -357 & 76 \\
\hline TG7-S08 & $\mathrm{J}$ & 2,68 & $-25,27$ & 200 & 25 & 1654 & 1955 \\
\hline TG7-S09 & $\mathrm{L}$ & 0,11 & $-29,71$ & 25310 & $+3160 /-2260$ & - & - \\
\hline
\end{tabular}

${ }^{\mathrm{a}}$ Radiocarbon dating are calibrated ( $\sigma \sigma$ range, $95.4 \%$ probability density) using Oxcal v4.0 [Bronk Ramsey, 2009] and INTCAL98 calibration curve of Stuiver et al. [1998].

necessarily younger than this large age bracket due to the absence of a datable sample in unit $\boldsymbol{f}$.

[35] Trench T2 (Figure 6) exposes two impressive deformation zones: $\mathrm{a} \sim 0.5$-m-thick shear zone with oriented gravels and pebbles, breccias and a well expressed gouge zone indicating repeated faulting episodes and a graben-like with several fault splays effecting the lacustrine deposits (unit $\boldsymbol{x} 3$ ) up to the base of unit $\boldsymbol{d}$ (Figures 6 and 12). Near the main fault zone, another fault splay affects north dipping layers of unit $\boldsymbol{d}$ and $\boldsymbol{c}$ which are truncated and buried below unit $\boldsymbol{b}$. Close to the surface, unit $\boldsymbol{b}$ is displaced by the main fault zone. Although trench T2 exhibits a thick stratigraphic succession with different fault branches, all collected samples provide old ages (see Table 2) and unfortunately do not allow us to determine the timing of successive faulting events. However, three faulting events older than unit $\boldsymbol{b}$ and sample TG2-W15 (48053963 BC) can be identified in this trench exposure. Although located on a $10^{\circ}$ slope, T2 was dug across at relatively high position (with respect to other trenches) showing truncated old sedimentary layers with limited colluvial deposits. These units seem to belong to an old perched sedimentary basin that can be interpreted as a small pull-apart basin along the fault zone. Therefore, the stratigraphic succession of T2 cannot be compared to other trenches T3, T4, $\mathrm{T} 5$ and T6 located in the alluvial fan area.

[36] A synthesis of faulting events visible in stratigraphic units and cumulative right-lateral slip of channel deposits (assuming characteristic slip at the Güzelköy paleoseismic site) is presented through the Oxcal Bayesian calculation (Figure 10). The timing of past earthquakes is proposed from the reconstruction of Figure 9. We also take into account the dating of lowermost layers of unit $\boldsymbol{l}_{\mathbf{2}}$ in T7 TG7-S05 dated $357 \mathrm{BC}-76 \mathrm{AD}$ (considering TG7-S09: $25319 \pm 3160 \mathrm{BP}$ as out of sequence radiocarbon dating) as an estimated maximum age for the total $21.3 \pm 1.5 \mathrm{~m}$ stream 2 offset and related 5 faulting events $\mathrm{V}, \mathrm{W}, \mathrm{X}, \mathrm{Y}$ and $\mathrm{Z}$. In addition, the constraint of the interseismic periods between events $\mathrm{W}$ and $\mathrm{X}$, and event $\mathrm{Y}$ and $\mathrm{Z}$ is made using three dating from channel unit $\boldsymbol{l}$ in T4 (TG4-E02: AD 1304-1443), unit $\boldsymbol{j}$ in T5 (TG5-S03: AD 1521-1955 and unit $\boldsymbol{k}$ in T6 (TG6-N01: AD 1666-1783). The radiocarbon dating from colluvial wedges in $\mathrm{T} 1$ and channel units $1, \mathrm{k}$ and $\mathrm{j}$ are here combined in order to constrain the successive faulting events and lateral offset at the paleoseismic site. 


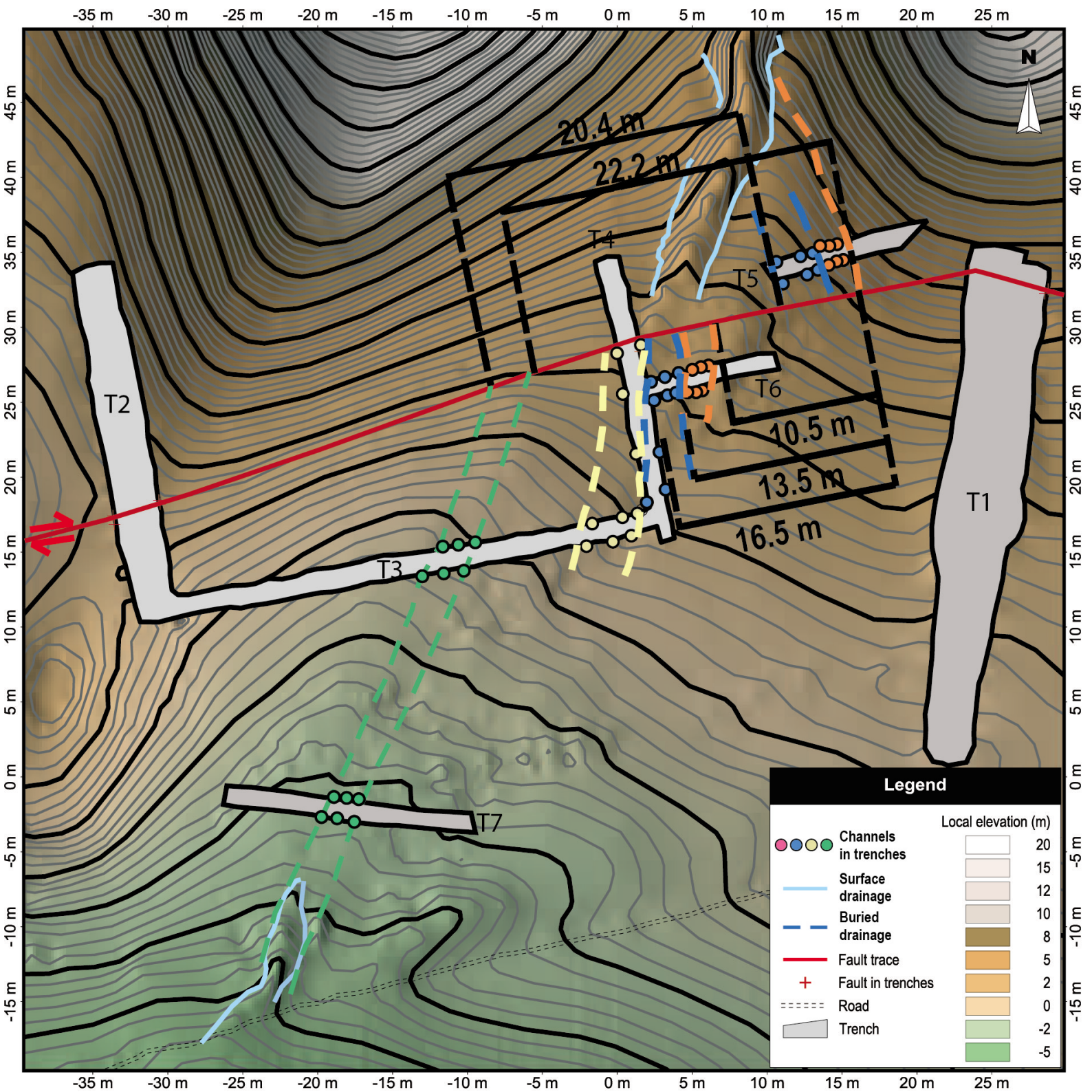

Figure 11. Distribution of buried channels observed in trenches. Numbers are estimated right-lateral cumulative displacements from channel offsets along the fault. Surveyed channel edges (as colored points) used for right-lateral offset estimates are also indicated in trench logs (T3, T4, T5, T6 and T7). Thick contour line is $1 \mathrm{~m}$ obtained from $0.5 \mathrm{~m}$ to $0.2 \mathrm{~m}$ leveling array points. Buried channels made of units $\boldsymbol{k}, \boldsymbol{l}$ and $\boldsymbol{j}$ in T5 north of the fault can be correlated with alluvial units in T6 and T4 south of the fault because they have comparable sedimentary content and they belong to the easternmost channel incisions. The comparison of channel geometry and content on both sides of the fault leads to $\sim 10.5,13.5$ and $16.5 \mathrm{~m}$ right-lateral cumulative offsets estimated from three channel edges (marked as orange, blue and yellow dots). The westernmost buried channel in T3 and T7, relative to the easternmost channel in T5 exhibits a maximum $22.2 \mathrm{~m}$ cumulative right-lateral offset at this site.

\subsection{Channel Offset and Right-Lateral Faulting Events}

[37] Past channel geometry can be traced across the fault zone using the precise location of stream and alluvial fan deposits (Figures 4 and 11).
The steep slope morphology at the Güzelköy paleoseismic site, combined with the intermittent stream dynamic, favor the formation of new stream channels following coseismic slip on the fault (Figures 12a and 12b). With the difficulty of intermittent river flows to generate new channel 
Table 4. List of Paleo-earthquakes Identified From Dated Faulting Episodes V, W, X; Y and Z, Related Pre- and Post-event Deposits Visible in Trenches and Corresponding Historical Earthquakes $(\mathrm{M}>7 \text { [Ambraseys, 2002] })^{\mathrm{a}}$

\begin{tabular}{|c|c|c|c|c|c|c|}
\hline Events & $\begin{array}{c}\text { Date of } \\
\text { Paleoearthquake AD } \\
(>\text { older than } /<\text { younger than })\end{array}$ & $\begin{array}{c}\text { Date of Historical } \\
\text { Earthquake AD }\end{array}$ & $\begin{array}{l}\text { Faulting } \\
\text { Event }\end{array}$ & $\begin{array}{l}\text { Post-event } \\
\text { Deposits }\end{array}$ & Interval (yr) & $\Delta(\mathrm{yr})$ \\
\hline $1-Z$ & 1912 & 09.08 .1912 & affects $b$ & colluvial wedge a & - & - \\
\hline $2-\mathrm{Y}$ & $1429-1776$ & 1659 or 1766 & affects c & colluvial wedge truncated & 199 & 54 \\
\hline $3-X$ & $1311-1397$ & 1343 or 1354 & affects d & colluvial wedge $\mathrm{c}$ & 364 & 59 \\
\hline $4-W$ & $692-1320$ & 823 or 1063 & affects e & colluvial wedge $\mathrm{d}$ & 406 & 126 \\
\hline $5-V$ & BC 258 to $200 \mathrm{AD}$ & $?$ & affects $\mathrm{f}$ & colluvial wedge e & - & - \\
\hline
\end{tabular}

${ }^{a}$ The estimated dating is from the earthquake sequence analysis (Bayesian) of Figure $10(\Delta$ (yr) is the uncertainty in the recurrence interval).

incisions in a relatively flat morphology, stream 2 of the Güzelköy paleoseismic site is related with at least 3 to 4 channels due to successive fault displacements.

[38] From north to south, trenches T5, T6 and T4, $\mathrm{T} 3$ and T7 expose a set of consecutive channels that correspond to abandoned stream incisions, likely due to the past fault movements. A comparable stratigraphic succession observed in T5, T6, T4, T3 and $\mathrm{T} 7$ indicates that a relatively young channel unit $\boldsymbol{j}$ overlaps units $\boldsymbol{k}$ and $\boldsymbol{l}$ of an older channel. Stream offsets are measured using channel edges and bottom taken as piercing points and measured during total station surveys (see colored circles in Figure 11). Total station measurements and related uncertainties allow correlation between paleochannel edges and bottom visible in trenches, and ridge block morphology, mapped on both sides of the fault. When matching the eastern edges of buried channels in trenches T5 and T6, located on both sides and close to the fault (see orange dots in Figure 11), we measure $10.5 \pm 0.5 \mathrm{~m}$ cumulative right-lateral offset that includes the 1912 slip at this site. This cumulative amount of slip is very comparable to $\sim 11 \mathrm{~m}$ measured on the nearby stream 1 (Figure 4). Both trenches provide radiocarbon ages of channels with AD 1521-1955 for T5 and 1666-1783 for T6 and suggest that the cumulative slip took place during the large age bracket AD 1429 to AD 1912 (from Figure 10). As observed during the 1912 earthquake [Aksoy et al., 2010], a maximum $5.5 \mathrm{~m}$ characteristic slip per event at this site, implies that the last two earthquakes $\mathrm{Y}$ and $\mathrm{Z}$ occurred since $\mathrm{AD} 1429$ and may be correlated with the 1659 or 1766 and 1912 large events of the historical catalog (Table 4) [Ambraseys, 2002].

[39] The eastern edge of the lowermost channel in trench T3 (yellow dots in Figures 7a and 7b) is located $\sim 5 \mathrm{~m}$ west of lowermost channels in T6

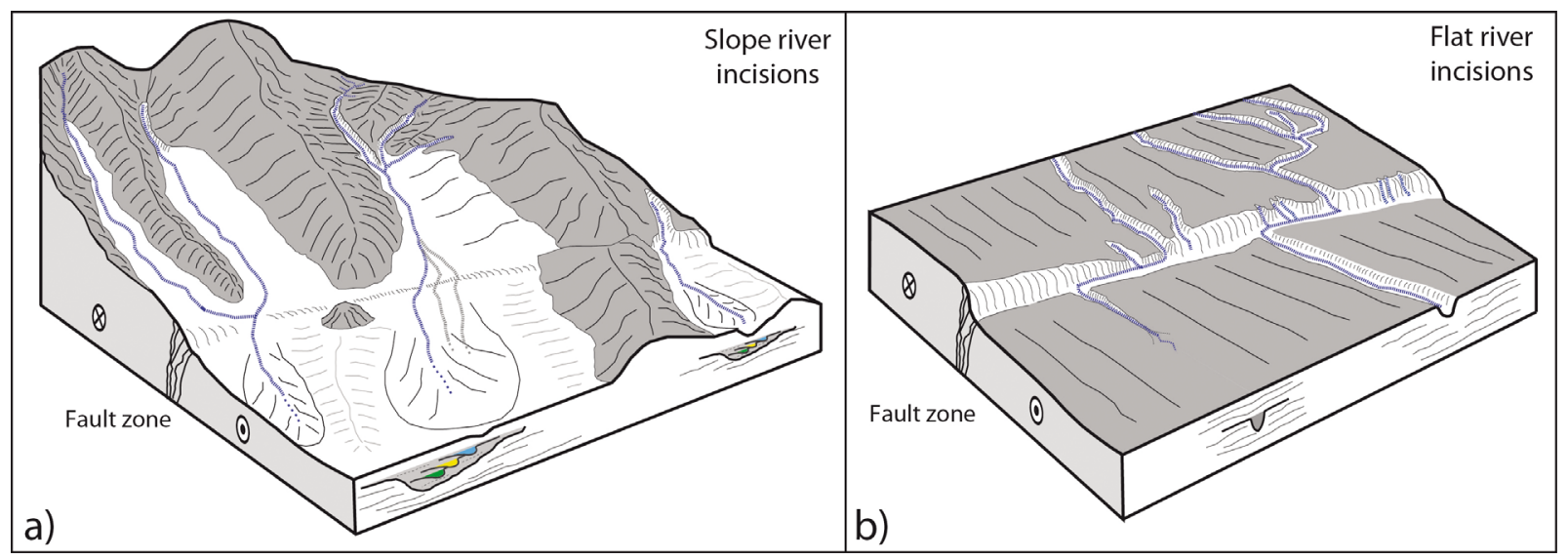

Figure 12. Block diagrams illustrating two different semi-arid landscapes with stream offsets along a right-lateral strike-slip fault. (a) In the steep slope morphology the high flow energy produces new channel incisions and offset streams will also be expressed as overlapping channel deposits (see for instance successive channels in T7). (b) In a nearly flat morphology, the offset streams are preserved on both sides of the fault as a single channel, owing to the low stream power. 
Table 5. Dated Offset Channels in Trenches and Ridge (as Mapped in Figure 4) ${ }^{\mathrm{a}}$

\begin{tabular}{lccccc}
\hline \multicolumn{1}{c}{ Offset Feature } & Cum. Offset $(\mathrm{m})$ & $\Delta(\mathrm{m})$ & Coseismic Offset $(\mathrm{m})$ & $\Delta(\mathrm{m})$ & Oldest Event (AD/BC) \\
\hline Surface channel & 5.5 & 0.5 & 5.5 & 0.5 & 1912 \\
Channel I in T5 and T6 & 10.5 & 0.5 & 5 & 0.5 & 1659 or 1766 \\
Channel I in T3 to T6 & 16.5 & 1.5 & 6 & 0.5 & 1343 or 1354 \\
Channel I in T5 and T7 & 21.3 & 1.5 & 4.8 & 0.5 & 823 or 1063 \\
Main ridge & 35.4 & 1.5 & - & - & -1042 to 76 \\
Saros Bay [Rockwell et al., 2009] & 9 & 1 & 4.5 & 0.5 & 1766 \\
\hline
\end{tabular}

${ }^{a}$ The most recent average slip at the site is inferred from the of 1912 earthquake report and field measurements [Aksoy et al., 2010]. The uncertainty in offset measurements $\Delta(\mathrm{m})$ is estimated from trenches, microtopographic survey and geomorphology of faulted alluvial units at the site (see also Figure 11).

(orange dots in Figures 8c and 11) along the fault. Taking into account that unit $\boldsymbol{l}$ in $\mathrm{T} 3$ is dated AD 1481-1898 (Figure 7a and TG3-S100 in Table 3) and that in T4 (Figure 8a) sample TG4-E02 is dated AD 1304-1443, we suggest that the $\sim 5 \mathrm{~m}$ offset between lowermost channels in $\mathrm{T} 6$ and $\mathrm{T} 3$ took place after AD 1304 (or 1311 in Figure 3) and may correspond to the earthquake event X. Event X may hence be correlated with the 1343 large event of the historical catalog [Ambraseys, 2002]. As shown in Figure 11, the total cumulative $16.5 \pm 1.5 \mathrm{~m}$ rightlateral offset between $\mathrm{T} 5$ and $\mathrm{T} 3$ across the fault may correspond to faulting events $\mathrm{X}, \mathrm{Y}$ and $\mathrm{Z}$ that occurred since AD 1311 (Table 4 and Figure 10).

[40] Trenches T5 and T7 exhibit paleo-channels that mark the maximum cumulative right-lateral offset along the fault. The total right-lateral offset estimated from the eastern edge, central position and western edge of each channel section, yields an average $21.3 \pm 1.5 \mathrm{~m}$ correlated with the 4 most recent faulting events since AD 692. Furthermore, the basement ridge block morphology mapped in Figure 4 displays $\sim 35.4 \mathrm{~m}$ maximum cumulative slip since $1042 \mathrm{BC}$, possibly related with the 7 most recent earthquake events, assuming 5 to $5.5 \mathrm{~m}$ characteristic slip at the Güzelköy paleoseismic site (Table 5).

\section{Discussion}

[41] The combined study of geomorphology and paleoseismic trenching at the Güzelköy paleoseismic site provides constraints on the timing of successive faulting and related past earthquakes along the eastern section of the Ganos fault. Our previous field investigations on the 1912 earthquake slip distribution and cumulative stream offsets along the Ganos fault [Altunel et al., 2004; Aksoy, 2009] helped in the paleoseismic site selection and estimating the long-term faulting behavior. The Güzelköy paleoseismic site is located on a fault section where the co-seismic slip of the 1912 earthquake is reaching a maximum of $5.5 \mathrm{~m}$. Earlier co-seismic displacements are collocated with well preserved $10.5 \pm 0.5 \mathrm{~m}$ to $21.3 \pm 1.5$ cumulative stream offsets and $35.4 \pm 1.5 \mathrm{~m}$ total offset of the basement ridge block outcrop, which indicate a characteristic behavior of $5-5.5 \mathrm{~m}$ slip at this site (Table 5).

[42] Total station measurements include trench observations on faults and buried channels. The $\pm 1.5 \mathrm{~m}$ uncertainty of measurements is determined from: $\mathrm{i}$ - The instrumental error range of a few $\mathrm{cm}$ of the total station, and ii - the sharpness of the paleo-channel edges and maximum bottom, and of the basement ridge block. As shown in the aerial photograph of Figure 4, the landform is well visible with minor vegetation cover and clearly exposed geomorphic features (stream incisions and channels, ridge blocks). The relatively steep slope morphology induces deep river incisions with sharp channel edges, which allows a noteworthy precision in offset measurement over sites with nearly flat morphology (e.g., the error bar of the western stream offset is well constrained because the stream incision is sharp and the edges are linear due to the stream entrenchment on the slope morphology; Figures 4 and 14). Additionally, in these morphological conditions, lateral fault movement combined with intermittent stream activity (i.e., dry in summer) favor newly formed and overlapping stream channels and preserve the co-seismic slip of past earthquakes. This typology contrasts with flat channel morphology and low energy water discharge, where in some cases, due to repeated and fast fault movement $(>1 \mathrm{~cm} / \mathrm{yr})$, only a single stream channel can be preserved (Figure 12b). A similar case study of an offset stream on the Serghaya fault branch of the northern Dead Sea Fault shows buried overlapping channels with $\sim 2.5 \mathrm{~m}$ left-lateral coseismic slip [Gomez et al., 2003]. Successive 
channels are hence visible in trenches with older deposits, representing both the maximum cumulative lateral offset and the coseismic displacement for several events (Figure 12a).

[43] Among all collected samples, the radiocarbon analysis of 25 samples provides exploitable dating results (see Table 3). Some samples with fairly good amount of carbon content allowed us the bracket of faulting events. However, the small amount of organic matter in the alluvial fan deposits made it difficult to obtain well resolved ages of paleo-earthquakes at the paleoseismic site. The poor organic and charcoal content of samples, probably due to the fast alluvial accumulation in channels and the high topographic gradient that favor detrital charcoal transport, and sample contamination mainly by roots (also indicated by the numerous large $\Delta C^{13}$ in Table 3), contribute to the large uncertainties in the age determination of past events. A major limitation in paleoseismology and related dating methods is the difficulty to correlate faulting events $\mathrm{W}, \mathrm{X}$ or $\mathrm{Y}$ and respective bracketed ages to specific historical earthquakes (see Table 4 and probability density function of Figure 10 in Figure 14). Nevertheless the available dating results supply some relevant constraint on the timing of past earthquakes and ages of offset structures, slip rate and recurrence interval for the western section of NAF.

\subsection{Timing of Past Earthquakes and Recurrence Interval}

[44] The paleoseismic results from trenches indicate the occurrence of five faulting events $(\mathrm{V}, \mathrm{W}, \mathrm{X}, \mathrm{Y}$ and $Z$ ) identified mainly from buried ruptures and the successive colluvial wedge deposits $\boldsymbol{e}, \boldsymbol{d}, \boldsymbol{c}, \boldsymbol{o}$ and $\boldsymbol{a}$ in trench T1 and from the right-lateral offset of buried paleo-channels visible in trenches T5, T6, T4, T3 and T7. Faulting events $\mathrm{X}, \mathrm{Y}$ and $\mathrm{Z}$ in trench T1 dated as post AD 1311-1397 (from Oxcal Bayesian calculation, see Figure 10) may be correlated with the $16 \pm 1.5 \mathrm{~m}$ lateral offset of paleo-channel dated post AD 1304-1443, measured in parallel trenches $\mathrm{T} 5, \mathrm{~T} 6$ and $\mathrm{T} 3$ and located immediately north and south to the fault. The total right-lateral offset reaches three times the 1912 slip. Earlier events $\mathrm{W}$ and $\mathrm{V}$ are dated by ages obtained from the Oxcal Bayesian calculation (Figure 10) AD 692-1320 and BC 258-200 AD respectively. For further precision, a correlation of obtained ages with historical large earthquakes reported in the seismicity catalog of the Sea of Marmara region yield limited constraint (Tables 1 and 4) [Ambraseys,
2002]. As shown in Table 4, except for the 1912 event, we faced difficulty to assign the rupturing event $Y$, to either the 1659 or 1766 earthquakes and event $X$, to either the 1343 or 1354 earthquakes. The correlation between older earthquake events $\mathrm{V}$ and $\mathrm{W}$ visible in $\mathrm{T} 1$ and cumulative fault offsets is as well difficult to establish. Dating results for event W (Figure 10) encompass a large time range that includes two historical events in AD 1063 and AD 823, and both are considered to have occurred on the Ganos fault [Ambraseys, 2002].

[45] The comparison of historical seismicity catalog of Table 1 and dating results of faulting events allows us also to calculate a recurrence interval for the Ganos fault segment. The intervals of $199 \pm 54$, $364 \pm 59$ and $406 \pm 126$ yrs for the last 4 events as given in Table 4, yields a recurrence interval of $323 \pm 142$ yrs for large earthquake with maximum coseismic slip of 5-6 m. The large age brackets for some events (e.g., Y and W) have a large influence on the recurrence interval estimation and are due to limited dating results that restrict us to define the appropriate event from the historical catalogs. Considering the calculated recurrence intervals of approx. 300 years for the Ganos region from our and other studies [Rockwell et al., 2009], it should be noted that the dating results for events prior to $\mathrm{X}$ may likely be misleading. For instance, the 484 AD historical earthquake (Table 1 and Figure 14) that should be identified in trenches as event V (dated $258 \mathrm{BC}-200 \mathrm{AD}$ in Oxcal sequence of Figure 10) cannot be resolved with the radiocarbon dating unless we replace sample TG1-E12 (AD 79230) by TG1-E09 (AD 653-769) of unit $\boldsymbol{e}$ in T1 in the Oxcal sequence.

\subsection{Slip Rate Estimates}

[46] The long-term faulting behavior and slip rate of the Ganos segment of the NAF may be well constrained at the Güzelköy paleoseismic site (Table 5). The most recent two events reaching 10 to $11 \mathrm{~m}$ right-lateral slip since AD 1429 (Figure 10) yield $21.7 \pm 1 \mathrm{~mm} / \mathrm{yr}$ slip rate, and reflect the consistency between the 5 to $5.5 \mathrm{~m}$ co-seismic characteristic slip (as measured for the 1912 event at this site, Table 5) and the cumulative offset of paleochannels visible in trenches T5 and T6. A noteworthy observation is the correlation between the $10.5 \pm 0.5 \mathrm{~m}$ right-lateral offset measured from paleo-channels in T5 and T6 and the nearby (western) stream 1 deflection that also cumulates $\sim 11 \mathrm{~m}$ slip likely due to the two more recent characteristic slip events (Figure 4). Taking into account the 


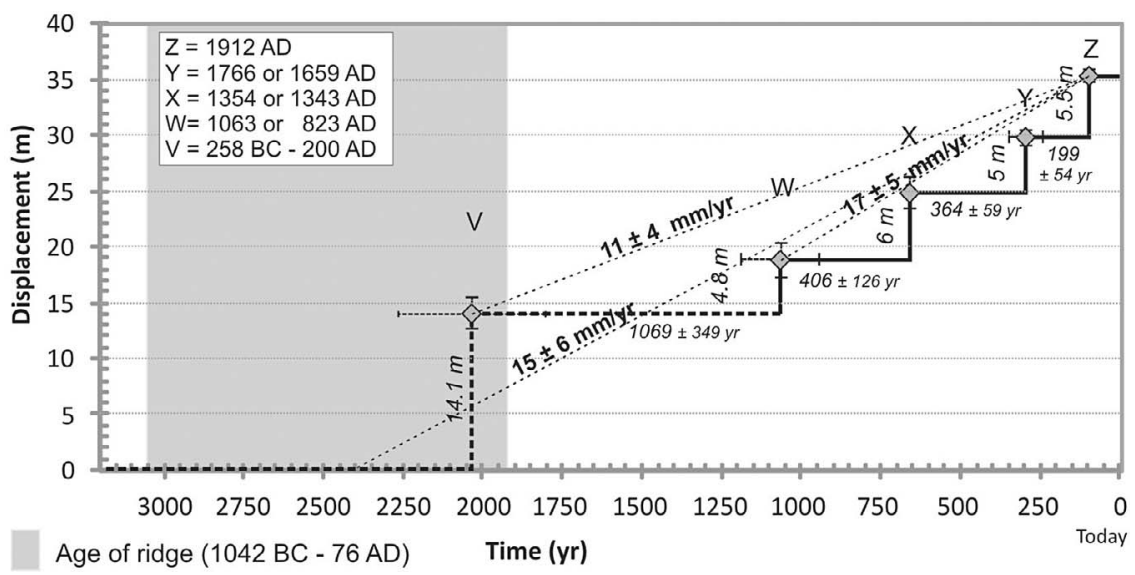

Figure 13. Slip distribution over time from paleoseismology along the Ganos segment of the North Anatolian fault (see also Table 5). The slip rate shows a variable distribution with $\sim 17 \mathrm{~mm} / \mathrm{yr}$ for the last 1000 years and $\sim 15 \mathrm{~mm} / \mathrm{yr}$ for the last 2500 years. Uncertainties are as a function of the age bracket of each past events and error range in offset measurements (see text for explanation). Upper left ages of past events are correlated with historical earthquakes except for event $\mathrm{V}$ that refers to Figure 10. The age of main ridge (gray section) is inferred from the dating in Trench $\mathrm{T} 1$ and $\mathrm{T} 7$ also reported in Tables 3 and 5.

$\sim 16.5 \pm 1.5$ m cumulative offset of paleo-channels of trenches $\mathrm{T} 5$ and $\mathrm{T} 3$, and related maximum age $\mathrm{AD} 1311$ from the earthquake sequence of Figure 10, we obtain a maximum $27.5 \pm 3 \mathrm{~mm} / \mathrm{yr}$ right-lateral slip rate along the fault. This maximum slip rate corresponds to the occurrence of faulting events $\mathrm{X}, \mathrm{Y}$ and $\mathrm{Z}$, for which a $5.5 \mathrm{~m}$ right-lateral characteristic slip is attributed (in agreement with event Z-1912 coseismic slip at the Güzelköy site). If the total $21.3 \pm 1.5 \mathrm{~m}$ deflection of stream 2 is related with the occurrence of paleoearthquakes $\mathrm{W}$, $\mathrm{X}, \mathrm{Y}$ and $\mathrm{Z}$ since $\mathrm{AD}$ 692, and assuming 5 to $5.5 \mathrm{~m}$ slip/event, we obtain $17.5 \pm 1 \mathrm{~mm} / \mathrm{yr}$ slip rate. Similarly, the $35.4 \pm 1.5 \mathrm{~m}$ maximum cumulative right-lateral offset of the basement ridge in between stream 1 and stream 2 (Figure 4) likely corresponding to 6 or 7 faulting events, predated by unit $\boldsymbol{g}$ dated 1042-835 BC in T1 (sample TG1-E03 in Table 3), and postdated by the older alluvial unit $\boldsymbol{l}_{\mathbf{2}}$, dated $357 \mathrm{BC}-76 \mathrm{AD}$ in $\mathrm{T} 7$, yields 11 to $17 \mathrm{~mm} / \mathrm{yr}$.

[47] The constraint of past faulting events with historical seismic events presented in Table 4 correlates each slip with a past earthquake (Table 5) and determines the seismic cycle. As a result, the linear regression of Figure 13 yields $17 \pm 5 \mathrm{~mm} / \mathrm{yr}$ right-lateral slip rate for the last 3 events in 1000 years at this site for the Ganos fault segment of the NAF. Considering the results over the last 4 events ( $\sim 2000$ years), the average slip rate reduces to $11 \pm$ $4 \mathrm{~mm} / \mathrm{yr}$. However, the large time interval prior to event $\mathrm{W}(\sim 1070 \mathrm{yrs})$ may include at least 3 seismic cycles when the $323 \pm 142$ recurrence interval is taken into account and would imply $4.7 \mathrm{~m}$ maximum co-seismic slip per event within the remaining $\sim 14 \mathrm{~m}$ cumulative slip (Figure 13). Using the largest $35.4 \pm 1.5 \mathrm{~m}$ offset of the ridge block and related large age bracket 1042 BC and $76 \mathrm{AD}$, an average $15 \pm 6 \mathrm{~mm} / \mathrm{yr}$ slip rate can be calculated for the last $\sim 2400$ years.

[48] The slip rate estimation may vary significantly due to uncertainties in offset measurements, dating results and undetermined seismic cycles, as presented in Table 5 and Figure 13. Even so, the average $17 \pm 5 \mathrm{~mm} / \mathrm{yr}$ slip rate with well constrained co-seismic slip and timing of inter-seismic periods represents a reliable estimate over the last 1000 years. The value is comparable with the trench results near Saros Bay, where Rockwell et al. [2009] calculate a $15.8(+7.3 /-3.8) \mathrm{mm} / \mathrm{yr}$ slip rate, by assuming $4.5 \mathrm{~m}$ characteristic slip and $284 \pm 90$ years recurrence interval for the last 4 events. The maximum $27.5 \mathrm{~mm} / \mathrm{yr}$ slip rate inferred from the cumulative slip for the last $\sim 600$ years includes the 14th century coseismic slip; however, it excludes the corresponding previous inter-seismic period and may result in an overestimation. Compared to the $22-26 \mathrm{~mm} / \mathrm{yr}$ loading rate obtained from $\sim 17$ years GPS measurements [McClusky et al., 2000; Reilinger et al., 2006] our slip rates are slightly lower than the geodetic velocities. In fact, the geodetic rate obtained by the dense GPS network installed after the 1999 earthquake across the northern branch of NAF is a short period of the seismic cycle and may reflect the short-term active deformation near the fault. 


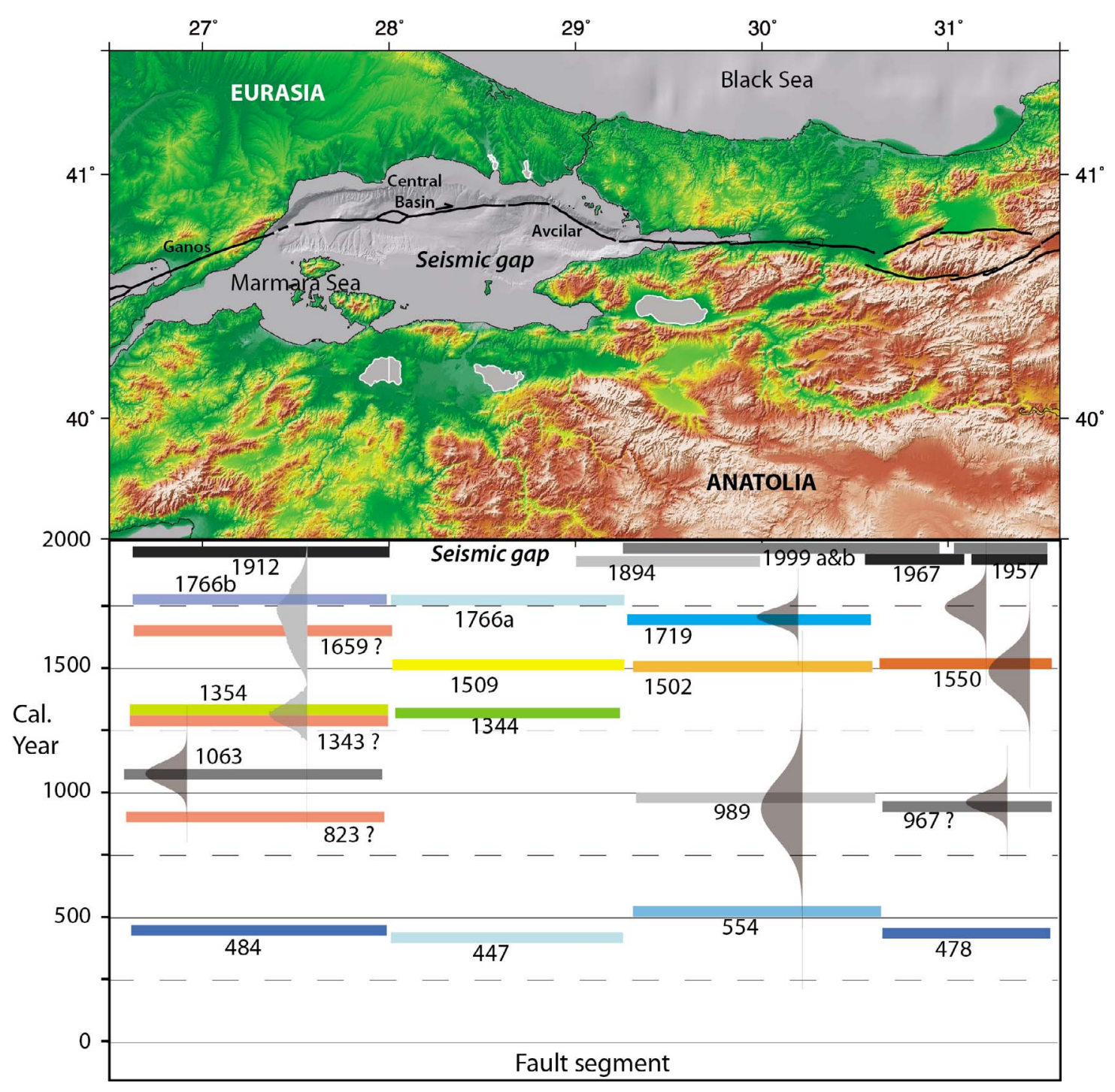

Figure 14. Earthquake sequences (seismic cycle) on each fault segment of the NAF and the seismic gap in the Marmara region. The analysis of spatial and temporal distribution of earthquakes consists in the combination of the historical seismicity (Figure 1) [Ambraseys, 2002], fault geometrical complexities, and paleoseismic timing of past earthquakes (1912 segment [Rockwell et al., 2001, 2009; Aksoy et al., 2010; this study]; 1999 İzmit segment [Klinger et al., 2003; Pavlides et al., 2006; Dikbass and Akyüz, 2011]; 1999 Düzce segment [Pantosti et al., 2008]; 1967 segment [Palyvos et al., 2007]). The probability density function indicates the error bar in the timing of past events. Pink segments representing historical earthquakes with question marks on the Ganos segment shows the unresolved size and location of events in seismicity catalog (some of these earthquakes may be located further southwest of Saros Bay) and their correlation with paleoseismic events. Each fault segment shows a periodic succession of five large events except for the Marmara segment that locate the seismic gap.

[49] Geological slip rates have been the focus of different studies inland and in the Marmara Sea along the NAF. Using structural geology, tectonic geomorphology and paleoseismic trenching, most slip rates range between 14 and $23 \mathrm{~mm} / \mathrm{yr}$ [Armijo et al., 1999; Hubert-Ferrari et al., 2002; Armijo et al., 2005; Hartleb et al., 2006; Pavlides et al., 2006; Kondo et al., 2010; Kozacr et al., 2009; this study]. Lower bound slip rates over 10-15 ka obtained from the Marmara Sea bottom and along the fault zone are around $10 \mathrm{~mm} / \mathrm{yr}$ [Polonia et al., 2004; Gasperini et al., 2011]. Our estimated 17 and $15 \mathrm{~mm} / \mathrm{yr}$ paleoseismic slip rate is for 1000 years and 2400 years time duration, respectively, may illustrate the variable faulting activity and related earthquake cycle. Slip rate variability reaching a factor 2 to 3 over several ka are also determined from paleoseismic analysis along the San Andreas 
fault [Weldon et al., 2004] and displaced lacustrine terraces along the Dead Sea fault [Ferry et al., 2007]. This variation in slip rate estimates along the NAF can be explained by a combination of two causes: 1) The error range in the age bracket of faulting events inherent to the sample collection for isotopic dating, and 2) the variable amount of slip/event and interseismic period at a given paleoseismic site during past events. Taking into account the earthquake sequence distribution versus the elapsed time, the estimated slip rate of the Güzelköy paleoseismic site varies from 15 to $17 \mathrm{~mm} / \mathrm{yr}$ and clearly depends on the time frame in which the slip rate is obtained and uncertainties in measurements (Figure 13). Furthermore, the discrepancy between the $\sim 17 \mathrm{~mm} / \mathrm{yr}$ long-term slip rate on the fault and $22-26 \mathrm{~mm} / \mathrm{yr}$ velocity rate from GPS may be due to the physical properties of fault ruptures [Reilinger et al., 2006; Chery and Vernant, 2006]. Slip rate on faults is clearly not linear over several thousand of years and its interpretation that depends on the seismic cycle is critical for the seismic hazard assessment.

\subsection{Seismic Hazard Implications}

[50] The paleoseismic study of the Güzelköy site, complemented with the detailed investigation of the 1912 slip distribution and cumulative stream offset along the Ganos segment of the NAF, help to assess the seismic hazard for both, the western Marmara and the forthcoming earthquake in the central Marmara regions. Our results document the active faulting behavior over the last 2400 years and provide some constraints on the seismic cycle of the NAF west of the Marmara Sea. An average maximum coseismic displacement $(U)$ that would signify the size of future earthquakes at Ganos, can be obtained from the relation $U=R t \times S r$, where $R t$ is the average recurrence time and $S r$ the average slip rate. The $17 \mathrm{~mm} / \mathrm{yr}$ and $15 \mathrm{~mm} / \mathrm{yr}$ slip rates with the average 323 year of recurrence time imply a maximum coseismic displacement of $5.5 \mathrm{~m}$ and $4.9 \mathrm{~m}$ respectively, which correlate to faulting events of minimum 7.3 to 7.4 moment magnitude and minimum $90 \mathrm{~km}$ surface faulting [Wells and Coppersmith, 1994].

[51] The likely size of a future earthquake east of the Ganos fault segment depends on the fault segmentation in the Marmara seismic gap and its interaction with most recent co-seismic ruptures (i.e., the 1999 and 1912 earthquake fault ruptures [Hubert-Ferrari et al., 2000; Aksoy, 2009]). Hence, the $17 \pm 5 \mathrm{~mm} / \mathrm{yr}$ rate of active faulting in the last 1000 years and recurrence time of large earthquakes obtained from our paleoseismic study confirms the level of seismic hazard in the Sea of Marmara. Although large uncertainties may exist on the size and location of past earthquakes in the Marmara Sea region, the combination of paleoseismic studies with the historical seismicity catalog points to the existence of the seismic gap in the Marmara Sea (Figure 14). The size of the seismic gap between the Avcrlar basin to the east and the Central Basin to the west is here constrained by the extent of the 1912 and 1999 fault segments [Barka et al., 2002; Le Pichon et al., 2003; Armijo et al., 2005; Aksoy et al., 2010]. The average slip rate combined with the repeated sequence of large earthquakes along fault segments since the 5 th century suggest $\sim 4$ to $5 \mathrm{~m}$ slip deficit at the seismic gap since 1766 .

\section{Conclusion}

[52] Paleoseismic investigations and geomorphic measurements of offset streams at the Güzelköy site and Ganos segment of the North Anatolian Fault reveal the occurrence of five faulting events $\mathrm{V}$ (BC 1042 to $76 \mathrm{AD}), \mathrm{W}$ (AD 692-1320), X (AD 13111397), Y (AD 1429-1776) and Z being the 1912 earthquake (Table 4). Besides the most recent 1912 earthquake, faulting events may correlate with historical earthquakes 1659 or 1766 (for event Y), 1354 or 1343 (for event X), and 823 or 1063 (for event W). Quantitative geomorphology indicates that faulting events $\mathrm{X}, \mathrm{Y}$ and $\mathrm{Z}$ indentified in trench T1 and dated post AD 1311-1397 may also be correlated with $16 \pm 1.5 \mathrm{~m}$ lateral offset of a paleochannel dated post AD 1304-1443 (Table 5). The successive fault ruptures recorded in the superficial deposits and geomorphology suggests 5 to $6 \mathrm{~m}$ characteristic slip per event over the last four events at the Güzelköy paleoseismic site (Figure 13). Radiocarbon dating of alluvial deposits in trenches combined with the offset channels, yield an average $17 \pm 5 \mathrm{~mm} / \mathrm{yr}$ right-lateral slip rate estimated for the last 1000 years (Figure 13); this average slip rate reduces to $15 \pm 6 \mathrm{~mm} / \mathrm{yr}$ if we consider the last five events in the last 2400 years. The average $323 \pm 142$ years recurrence interval for large earthquakes with $\mathrm{M}>7$ deduced from the $5.25 \mathrm{~m}$ coseismic displacement and $17 \mathrm{~mm} / \mathrm{yr}$ slip rate is comparable to the values of return period of major seismic events obtained on the eastern segments of the NAF [Hartleb et al., 2006; Kozacl et al., 2009; Kondo et al., 2010; Fraser et al., 2010]. The recurrence interval, variable slip rate and coseismic 
slip per faulting event suggest $\mathrm{Mw} 7.3$ to 7.4 earthquakes and a minimum $90 \mathrm{~km}$ fault length.

[53] Our paleoseismic results reinforce the previous inferences on the presence of a seismic gap in the Marmara Sea (Figure 14). The succession of past earthquakes east and west of the Marmara Sea, i.e., along the 1999 segment [Klinger et al., 2003; Pavlides et al., 2006; Pantosti et al., 2008; Dikbaş and Akyüz, 2011] and 1912 segment [Aksoy, 2009; this study] document the $\sim 4$ to $5 \mathrm{~m}$ characteristic slip. The dating of past earthquakes combined with historical earthquake distribution also constrains the seismic slip deficit since 1766 at the seismic gap (Figure 14). The study of past earthquakes and slip rate along the 1912 segment of NAF contributes to a better understanding of the seismic cycle in the Marmara Sea area. The slip rate variability shown in Figure 13 and irregular recurrence interval (Table 4) of large earthquakes along the Ganos segment may also be an analogue to the earthquake faulting behavior in the Marmara Sea. Our paleoseismological data and results document the long-term faulting behavior in the westernmost segment of the NAF (Figure 14); hence, they contribute to a better understanding of the fault rupture characteristics and seismic cycle in the Marmara Sea, and related seismic hazard evaluation in the Istanbul region.

\section{Acknowledgments}

[54] This work was supported by the RELIEF project (EC Contract EVG1-2002-00069). M. E. Aksoy benefited from a fellowship from the French Embassy in Ankara. This work is dedicated to Aykut Barka who attracted our attention to several sites for paleoseismic investigations along the 1912 NAF segment. Our special thanks go to the villagers near Güzelköy, to Lüftiye and Celal for their hospitality and to Stefano Pucci for the kite photographs. We are grateful to Ziyadin Çakır, Tom Rockwell, Daniela Pantosti, Gülsen Uçarkuş, Cengiz Zabcı, Paolo-Marco de Martini, Çağlar Yalçıner, Ahmet Akoğlu and Mathilde Sorensen for fruitful discussions and assistance in the field. We thank Thorsten Becker (Editor), Luca Gasperini and an anonymous reviewer for their comments and suggestions on an earlier version of manuscript.

\section{References}

Aksoy, M. E. (2009), Active tectonics and paleoseismology of the Ganos fault segment and seismic characteristics of the 9 August 1912 Mürefte Earthquake of the North Anatolian Fault (Western Turkey), PhD dissertation, 304 pp., İstanbul Teknik Univ., Istanbul, Turkey.

Aksoy, M. E., M. Meghraoui, M. Vallee, and Z. Çakır (2010), Rupture characteristics of the A.D. 1912 Mürefte (Ganos) earthquake segment of the North Anatolian fault (western Turkey), Geology, 38(11), 991-994, doi:10.1130/G31447.1.

Akyüz, H. S., R. Hartleb, A. Barka, E. Altunel, G. Sunal, B. Meyer, and R. Armijo (2002), Surface rupture and slip distribution of the 12 November 1999 Düzce Earthquake (M 7.1), North Anatolian Fault, Bolu, Turkey, Bull. Seismol. Soc. Am., 92(1), 61-66, doi:10.1785/0120000840.

Altınok, Y., B. Alpar, and C. Yaltırak (2003), Șarköy-Mürefte 1912 Earthquake's Tsunami, extension of the associated faulting in the Marmara Sea, Turkey, J. Seismol., 7(3), 329-346, doi:10.1023/A:1024581022222.

Altunel, E., M. Meghraoui, H. S. Akyüz, and A. Dikbaş (2004), Characteristics of the 1912 co-seismic rupture along the North Anatolian Fault Zone (Turkey): Implications for the expected Marmara earthquake, Terra Nova, 16(4), 198-204, doi:10.1111/j.1365-3121.2004.00552.x.

Ambraseys, N. N. (2002), The seismic activity of the Marmara Sea Region over the last 2000 years, Bull. Seismol. Soc. Am., 92(1), 1-18, doi:10.1785/0120000843.

Ambraseys, N. N. (2009), Earthquakes in the Mediterranean and Middle East: A Multidisciplinary Study of Seismicity up to 1900, 947 pp., Cambridge Univ. Press, Cambridge, U. K.

Ambraseys, N. N., and C. F. Finkel (1987), The Saros-Marmara earthquake of 9 August 1912, Earthquake Eng. Struct. Dyn., 15(2), 189-211, doi:10.1002/eqe.4290150204.

Armijo, R., B. Meyer, A. Hubert, and A. Barka (1999), Westward propagation of the North Anatolian fault into the northern Aegean: Timing and kinematics, Geology, 27, 267-270, doi:10.1130/0091-7613(1999)027<0267:WPOTNA >2.3.CO;2.

Armijo, R., et al. (2005), Submarine fault scarps in the Sea of Marmara pull-apart (North Anatolian Fault): Implications for seismic hazard in Istanbul, Geochem. Geophys. Geosyst., 6, Q06009, doi:10.1029/2004GC000896.

Barka, A. (1996), Slip distribution along the North Anatolian fault associated with the large earthquakes of the period 1939 to 1967, Bull. Seismol. Soc. Am., 86(5), 1238-1254.

Barka, A., and K. Kadinsky-Cade (1988), Strike-slip fault geometry in Turkey and its influence on earthquake activity, Tectonics, 7, 663-684, doi:10.1029/TC007i003p00663.

Barka, A., et al. (2002), The surface rupture and slip distribution of the 17 August 1999 İzmit Earthquake (M 7.4), North Anatolian Fault, Bull. Seismol. Soc. Am., 92(1), 43-60, doi: $10.1785 / 0120000841$.

Bronk Ramsey, C. (2009), Bayesian analysis of radiocarbon dates, Radiocarbon, 51(1), 337-360.

Chery, J., and P. Vernant (2006), Lithospheric elasticity promoted episodic fault activity, Earth Planet. Sci. Lett., 243, 211-217, doi:10.1016/j.epsl.2005.12.014.

Dikbaş, A., and H. S. Akyüz (2011), Palaeoseismological Investigations on the Karadere Segment, North Anatolian Fault Zone, Turkey, Turk. J. Earth Sci., 20(4), 395-410, doi:10.3906/yer-0911-50.

Ferry, M., M. Meghraoui, J.-F. Girard, T. K. Rockwell, O. Kozac1, S. Akyuz, and A. Barka (2004), Ground-penetrating radar investigations along the North Anatolian fault near İzmit, Turkey: Constraints on the right-lateral movement and slip history, Geology, 32(1), 85-88, doi:10.1130/G19949.1.

Ferry, M., M. Meghraoui, N. Abou Karaki, M. Al-Taj, H. Amoush, S. Al-Dhaisat, and M. Barjous (2007), A 48-kyr-long slip rate history for the Jordan Valley segment of the Dead Sea Fault, Earth Planet. Sci. Lett., 260, 394-406, doi:10.1016/j.eps1.2007.05.049.

Fraser, J., K. Vanneste, and A. Hubert-Ferrari (2010), Recent behavior of the North Anatolian Fault: Insights from an 
integrated paleoseismological data set, J. Geophys. Res., 115, B09316, doi:10.1029/2009JB006982.

Gasperini, L., A. Polonia, M. N. Çağatay, G. Bortoluzzi, and V. Ferrante (2011), Geological slip rates along the North Anatolian Fault in the Marmara Sea, Tectonics, 30, TC6001, doi:10.1029/2011TC002906.

Gomez, F., M. Meghraoui, A. Darkal, F. Hijazi, M. Mouty, Y. Sulaiman, R. Sbeinati, R. Darawcheh, R. Al-Ghazzi, and M. Barazangi (2003), Holocene faulting and earthquake recurrence along the Serghaya branch of the Dead Sea fault system in Syria and Lebanon, Geophys. J. Int., 153, 658-674, doi:10.1046/j.1365-246X.2003.01933.x.

Guidoboni, E., and A. Comastri (2005), Catalogue of Earthquakes and Tsunamis in the Mediterranean Area From the 11th to the 15th Century, Ist. Naz. di Geofis. e Vulcanologia, Rome.

Guidoboni, E., A. Comastri, and G. Traina (1994), Catalogue of Ancient Earthquakes in the Mediterranean Area up to the 10th Century, 504 pp., Ist. Naz. di Geofis. e Vulcanologia, Rome.

Hartleb, R. D., J. F. Dolan, O. Kozacı, H. S. Akyuz, and G. G. Seitz (2006), A 2500-yr-long paleoseismologic record of large, infrequent earthquakes on the North Anatolian fault at Çukurçimen, Turkey, Geol. Soc. Am. Bull., 118(7-8), 823-840, doi:10.1130/B25838.1.

Hecker, O. (1920), Mitteilungen über Erdbeben im Jahre 1912, 26 pp., Hauptstation für Erdbebenforschung, Jena, Germany.

Hubert-Ferrari, A., A. Barka, E. Jacques, S. S. Nalbant, B. Meyer, R. Armijo, P. Tapponnier, and G. C. P. King (2000), Seismic hazard in the Marmara Sea region following the 17 August 1999 İzmit earthquake, Nature, 404(6775), 269-273, doi:10.1038/35005054.

Hubert-Ferrari, A., R. Armijo, G. King, and B. Meyer (2002), Morphology, displacement, and slip rates along the North Anatolian Fault, Turkey, J. Geophys. Res., 107(B10), 2235, doi:10.1029/2001JB000393.

Klinger, Y., K. Sieh, E. Altunel, A. Akoğlu, A. Barka, T. Dawson, T. Gonzalez, A. Meltzner, and T. Rockwell (2003), Paleoseismic evidence of characteristic slip on the western segment of the North Anatolian Fault, Turkey, Bull. Seismol. Soc. Am., 93(6), 2317-2332, doi:10.1785/ 0120010270 .

Kondo, H., V. Özaksoy, and C. Y1ldırım (2010), Slip history of the 1944 Bolu-Gerede earthquake rupture along the North Anatolian fault system: Implications for recurrence behavior of multisegment earthquakes, J. Geophys. Res., 115, B04316, doi:10.1029/2009JB006413.

Kozac1, Ö., J. F. Dolan, and R. C. Finkel (2009), A late Holocene slip rate for the central North Anatolian Fault at Tahtaköprü, Turkey, from Cosmogenic ${ }^{10} \mathrm{Be}$ geochronology: Implications for fault loading and strain release rate, J. Geophys. Res., 114, B01405, doi:10.1029/2008JB005760.

Le Pichon, X., C. Chamot-Rooke, N. Rangin, and A. M. C. Şengör (2003), The North Anatolian fault in the Sea of Marmara, J. Geophys. Res., 108(B4), 2179, doi:10.1029/ 2002JB001862.

McCalpin, J. (2009), Paleoseismology, 385 pp., Academic, San Diego, Calif.

McClusky, S., et al. (2000), Global Positioning System constraints on plate kinematics and dynamics in the eastern Mediterranean and Caucasus, J. Geophys. Res., 105(B3), 5695-5719, doi:10.1029/1996JB900351.

McNeill, L. C., A. Mille, T. A. Minshull, J. M. Bull, N. H. Kenyon, and M. Ivanov (2004), Extension of the North Anatolian Fault into the North Aegean Trough: Evidence for transtension, strain partitioning, and analogues for Sea of Marmara basin models, Tectonics, 23, TC2016, doi:10.1029/2002TC001490.

Mihailovic, J. (1927), Trusne katastrofe na Mramornome moru, Posebno izdan, Srpske Akad. Nauka, 65, 1-303.

Okay, A. I., O. Tüysüz, and S. Kaya (2004), From transpression to transtension: Changes in morphology and structure around a bend on the North Anatolian Fault in the Marmara region, Tectonophysics, 391(1-4), 259-282, doi:10.1016/j. tecto.2004.07.016.

Palyvos, N., D. Pantosti, C. Zabc1, and G. D'Addezio (2007), Paleoseismological evidence of recent earthquakes on the 1967 Mudurnu Valley Earthquake segment of the North Anatolian Fault Zone, Bull. Seismol. Soc. Am., 97(5), 1646-1661, doi:10.1785/0120060049.

Pantosti, D., S. Pucci, N. Palyvos, P. M. De Martini, G. D'Addezio, P. E. F. Collins, and C. Zabc1 (2008), Paleoearthquakes of the Düzce fault (North Anatolian Fault Zone): Insights for large surface faulting earthquake recurrence, J. Geophys. Res., 113, B01309, doi:10.1029/2006JB004679.

Pavlides, S., A. Chatzipetros, S. Tutkun, V. Özaksoy, and B. Doğan (2006), Evidence for late Holocene activity along the seismogenic fault of the 1999 İzmit earthquake, NW Turkey, in Tectonics Development of the Eastern Mediterranean Region, edited by A. H. F. Robertson and D. Mountrakis, Geol. Soc. Spec. Publ., 260, 635-647.

Polonia, A., L. Gasperini, A. Amorosi, E. Bonatti, N. Çağatay, L. Capotondi, M.-H. Cormier, N. Görür, C. McHugh, and L. Seeber (2004), Holocene slip rate of the North Anatolian Fault beneath the Sea of Marmara, Earth Planet. Sci. Lett., 227, 411-426, doi:10.1016/j.eps1.2004.07.042.

Reilinger, R. E., et al. (2006), GPS constraints on continental deformation in the Africa-Arabia-Eurasia continental collision zone and implications for the dynamics of plate interactions, J. Geophys. Res., 111, B05411, doi:10.1029/ 2005JB004051.

Reimer, P. J., et al. (2009), IntCal09 and Marine09 radiocarbon age calibration curves, 0-50,000 years cal BP, Radiocarbon, 51(4), 1111-1150

Rockwell, T. K., A. Barka, T. Dawson, S. Akyüz, and K. Thorup (2001), Paleoseismology of the Gaziköy-Saros segment of the North Anatolia fault, northwestern Turkey: Comparison of the historical and paleoseismic records, implications of regional seismic hazard, and models of earthquake recurrence, J. Seismol., 5(3), 433-448, doi:10.1023/ A:1011435927983.

Rockwell, T. K., et al. (2009), Palaeoseismology of the North Anatolian Fault near the Marmara Sea: Implications for fault segmentation and seismic hazard, in Palaeoseismology: Historical and Prehistorical Records of Earthquake Ground Effects for Seismic Hazard Assessment, edited by K. Reicherter, A. M. Michetti, and P. G. Silva, Geol. Soc. Spec. Publ., 316, 31-54, doi:10.1144/SP316.3.

Sadi, D. Y. (1912), Marmara Havzasinın 26-27 Temmuz Hareket-i Arzı 15 Eylül 1328, vol. 45, Resimli Kitap Matbaası, İstanbul, Turkey.

Şaroğlu, F., Ö. Emre, and İ. Kuşçu (1992), Active fault map of Turkey, Miner. Res. Explor. Inst. Turk., Ankara.

Schwartz, D. P., and K. J. Coppersmith (1984), Fault behavior and characteristic Earthquakes: Examples from the Wasatch and San Andreas Fault Zones, J. Geophys. Res., 89(B7), 5681-5698, doi:10.1029/JB089iB07p05681.

Șengör, A. M. C., N. Görür, and F. Șaroğlu (1985), Strike-slip faulting and related basin formation in zones of tectonic escape: Turkey as a case study, in Strike-Slip Faulting and 
Basin Formation, edited by K. T. Biddle and N. Christie-Blick, Spec. Publ. Soc. Econ. Paleontol. Mineral., 37, 193-230.

Stein, R. S., A. A. Barka, and J. H. Dieterich (1997), Progressive failure on the North Anatolian fault since 1939 by earthquake stress triggering, Geophys. J. Int., 128, 594-604, doi:10.1111/j.1365-246X.1997.tb05321.x.

Stuiver, M., P. J. Reimer, E. Bard, J. W. Beck, G. S. Burr, K. A. Hughen, B. Kromer, G. McCormac, J. van der Plicht, and M. Spurk (1998), INTCAL98 Radiocarbon Age Calibration, 24000-0 cal BP, Radiocarbon, 40, 1041-1083.

Uçarkuş, G., Z. Çakır, and R. Armijo (2011), Western termination of the Mw 7.4, 1999 İzmit Earthquake rupture: Implications for the expected large earthquake in the Sea of Marmara, Turkish J. Earth Sci., 20(4), 379-394, doi:10.3906/ yer-0911-72.

Ustaömer, T., E. Gökaşan, H. Tur, T. Görüm, F. Batuk, D. Kalafat, H. Alp, B. Ecevitoğlu, and H. Birkan (2008), Faulting, mass-wasting and deposition in an active dextral shear zone, the Gulf of Saros and the NE Aegean Sea, NW Turkey, Geo Mar. Lett., 28(3), 171-193, doi:10.1007/ s00367-007-0099-6.

Weldon, R., K. Scharer, T. Fumal, and G. Biasi (2004), Wrightwood and the earthquake cycle: What a long recurrence record tells us about how faults work, GSA Today,
14, 4-10, doi:10.1130/1052-5173(2004)014<4:WATECW > 2.0.CO;2.

Wells, D. L., and K. J. Coppersmith (1994), New empirical relationships among magnitude, rupture length, rupture width, rupture area, and surface displacement, Bull. Seismol. Soc. Am., 84, 974-1002.

Yaltırak, C., and B. Alpar (2002), Kinematics and evolution of the northern branch of the North Anatolian Fault (Ganos Fault) between the Sea of Marmara and the Gulf of Saros, Mar. Geol., 190(1-2), 351-366, doi:10.1016/S0025-3227(02) 00354-7.

Yaltırak, C., M. Sakınç, and F. Y. Oktay (2000), Westward propagation of North Anatolian fault into the northern Aegean: Timing and kinematics: Comment and Reply: COMMENT, Geology, 28, 187-188, doi:10.1130/00917613(2000)28<187:WPONAF>2.0.CO;2.

Zabcı, C., H. S. Akyüz, V. Karabacak, T. Sancar, E. Altunel, H. Gürsoy, and O. Tatar (2011), Palaeoearthquakes on the Kelkit Valley Segment of the North Anatolian Fault, Turkey: Implications for the Surface Rupture of the Historical 17 August 1668 Anatolian Earthquake, Turkish J. Earth Sci., 20(4), 411-427, doi:10.3906/yer-0910-48. 